\title{
Notas sobre teología política en el Reino de Asturias: la inscripción del altar de Santa María de Naranco (Oviedo) $y$ el testamento de Alfonso II
}

\author{
César García de Castro Valdés
}

\begin{abstract}
RESUMEN
A partir del análisis de fuentes y comparativo del texto de la inscripción del altar procedente de Santa María de Naranco (Oviedo), el trabajo desarrolla una hipótesis de interpretación de las razones de la redacción de esta inscripción. A la vez, examinando el documento conocido como testamento de Alfonso II, se traza una vía de aproximación a la teología política subyacente en los reinados de Alfonso II (79)842) y Ramiro I (842-850), proyectándola contra el trasfondo europeo coetáneo.
\end{abstract}

PALABRAS CLAVE: Reino de Asturias; Santa María de Naranco; Arquitectura prerrománica asturiana.

El altar de Santa María de Naranco es pieza suficientemente conocida en la investigación sobre arquitectura altomedieval hispánica desde el momento de su recomposición en 1884 (CANELLA SECADES, I884; MIGUEL VIGIL, 1887: 218 219). Son abundantes los autores que han hecho referencia a esta pieza, bien en sus aspectos morfológicos (SCHLUNK, 1947: 355-358; ID, 1948: 98100; ID, 1976-80: 160- I 62; JORGE ARAGONESES, 1953; ÍNIIGUEZ ALMECH, 1955: 70; ARBEITER Y NOACKHALEY, 1999: 156-158) o epigráficos (HAUPT, 1935: 228-230; CAMPS CAZORLA, 1948: 98-100; ESCORTELL PONSODA, 1975: |3- | 4; DIEGO SANTOS, 1994: 101-103; GARCÍA DE CASTRO VALDÉS, 1995: 109-120; ID, 1999: 49-57). En la actualidad se conserva en el Museo Arqueológico de Asturias.

La mesa de altar en la que se grabó la inscripción es un bloque monolítico de caliza blan-

\begin{abstract}
RÉSUMÉ
Á partir de l'analyse comparative et des sources du texte de l'inscription de l'autel provenant de Santa María de Naranco (Oviedo, Espagne), cet article développe une hypothèse interprétative des motivations qui soutiennent sa rédaction. Paralèllement, en considérant le document connu comme donation de Alphonse II, on déplie une voie approximative vers la théologie politique aux alentours des royaumes de Alphonse I| (79|-842) et Ramire I (842-850), en la situant dans l'arrière-fond européen contemporain.
\end{abstract}

MOTS CLÉ : Royaume des Asturies ; Santa María de Naranco ; Architecture préromane asturienne.

ca cuyas dimensiones son $101 \times 80 \times 19$ centímetros. La superficie superior de la mesa tiene un reborde de unos siete centímetros de anchura, decorado con un motivo de tallo vegetal y hojas lanceoladas entre las ondas. En el centro del lado posterior se dispone una pequeña cruz griega de brazos patados y astil inferior, y en la esquina derecha de este mismo lado posterior se ha abierto el canalillo de desagüe para permitir la limpieza y evacuación de restos de la celebración eucarística. En el centro del tablero se ha rebajado el plano para insertar el ara de época barroca.

La inscripción se distribuye en los cuatro frentes de la pieza. En las caras frontal y laterales, un motivo de cuerda o espiga delimita arriba y abajo el campo epigráfico. En la cara posterior falta esta decoración, al ocupar tres líneas 
el desarrollo del texto, que abarca una línea en la cara frontal y la derecha, y dos en la cara lateral izquierda. Morfológicamente, Schlunk señaló en su momento un antecedente entre las mesas de altar paleocristianas con inscripción lateral, la desaparecida pieza de Salpensa (SeviIla), fechada en el año 642 (SCHLUNK-HAUSCHILD, 1978: 63). Recientemente, Arbeiter y Noack-Haley han aportado un nuevo paralelo, la mesa de altar ofrecida por el presbítero Proculus en Illiat (Grenoble) -aprox. 0'80 × 0'48 m(ARBEITER Y NOACK-HALEY, 1999: 157; REYNAUD, 1995: 194), fechada entre los siglos $V$ y VII, a lo que se puede añadir una tercera mesa de altar, la de Nuestra Señora de Le Ham (Manche), consagrada en 679 por el obispo Fromond de Coutances, labrada en caliza con unas dimensiones muy semejantes a la de Naranco - I'05 × 0'98 $\times$ 0'I4 m- (MUSSET, 1998: 280-28I). No obstante, el texto conservado de ambos paralelos difiere sustancialmente de lo inscrito en Naranco: en lliat, es un presbyter, Proculus, quien construye o manda construir la mesa; en Le Ham, corresponde al pontifex Frodomundus la construcción y la dedicación del templo y del altar (hoc templvm hocqvae altare constrvxit fideliter adquae digne dedicavit; DÜMMLER, I: 652-654). En el Naranco, por el contrario, y como ya hemos señalado en alguna ocasión, faltan completamente las referencias a los actos litúrgicos (GARCÍA DE CASTRO VALDÉS, 1995: I16).

\section{EL TEXTO DE LA INSCRIPCION DE SANTA MARIA DE NARANCO}

La lectura del texto no ofrece mayores dificultades, pese a alguna laguna fácilmente subsanable, y sobre ella existe consenso historiográfico. Su transcripción es la siguiente:

Cara frontal:

+ CHRISTE:FILIVS. DEI:QVI IN VTERO.VIRGINIS:BEATAE MARIAE.INGRESSVS ES SINE HV

Cara lateral derecha:

MANA:CONTEPTIONE ET EGRESSUS SINE CORRUPTIONE . QVI PER FAMVLVM

Cara posterior:
TVM RANIMIRVM PRINCIPE GLORIOSVM CVM PATERNA REGINA CONIVGE RENOVASTI HOC HABITACVLVM NIMIA VETVSTATE CONSUPTVM.ET PRO EIS AEDIFICASTI HANC HARAM BENEDIC

TIONIS.GLORIOSAE.SANTAE MARIAE: IN LOCVM . HVNC. SVMMVM : EXAVDI EOS DE CAELORVM HABITACVLO TVO ET DIMITTE PECCA

Cara lateral izquierda:

TA EORVM . QVI VIVIS ET REGNAS.PER INFINITA SAECVLA SAECVLORVM : AMEN.

DIE VIII O KALENDAS IVLIAS : ERA DCCCLXVI

En el trabajo aludido de 1995 advertíamos que este texto guarda un muy estrecho paralelo con las oraciones marianas, penitenciales y de difuntos de la liturgia hispánica. Se distinguen dos partes en el mismo: la invocación cristológica y la súplica penitencial. Pueden admitirse como fuentes de inspiración para cada una de las dos partes los siguientes textos:

- la primera parte de la oración alude al Misterio de la Encarnación del Verbo, en términos muy parecidos a los empleados en las oraciones mariológicas de la liturgia hispánica. Los textos más en consonancia con este aspecto del altar proceden del Liber Ordinum Episcopalis (números 112, 269 y 384), del Liber Missarum Toledano (números 103, 105 y 204) y del Oracional Veronense (números 213,220 y 310 ).

- la segunda parte de la oración se refiere al perdón de los pecados de los donantes. Los textos seleccionados proceden del Liber Ordinum Sacerdotalis (números 59, 62, 70, 89 y 93), del Liber Ordinum Episcopalis (números 199 y 714) y del Antifonario Legionense, sobre todo del Officium de Sacratione Baselice.

En esta segunda parte se inserta una narración alusiva al hecho de la renovación del edificio a cargo de Ramiro y Paterna. Su tenor recuerda significativamente la oración dedicatoria de Salomón en la ceremonia de consagración del templo de Jerusalén, transmitida en dos textos bíblicos: 
3 Reg, 8, 28-53. 1

Sed respice ad orationem servi tui, et ad preces eius, Domine Deus meus: audi hymnum et orationem, quam servus tuus orat coram te hodie: ut sint oculi tui aperti super domum hanc nocte ac die: super domum de qua dixisti. Erit nomen meum ibi: ut exaudias orationem, quam orat in loco isto ad te servus tuus. Ut exaudias deprecationem servi tui et populi tui Israel, quodcumque oraverint in loco isto, et exaudies in loco habitaculi tui in caelo, et cum exaudieris, propitius eris.

Si peccaverit homo in proximum suum, et habuerit aliquod iuramentum, quo teneatur astrictus: et venerit propter iuramentum coram altari tuo in domum tuam, tu exaudies in caelo: el facies, et iudicabis servos tuos, condemnans impium, et reddens viam suam super caput eius, iustificansque iustum, et retribuens ei secundum iustitiam suam.

Si fugierit populus tuus Israel inimicos suos (quia peccaturus est tibi) et agentes poenitentiam, et confitentes nomini tuo, venerint, et oraverint, et deprecati te fuerint in domo hac: exaudi in caelo et dimitte peccatum populi tui Israel, et reduces eos in terram, quam dedisti patribus eorum.

Si clausum fuerit caelum, et non pluerit propter peccata eorum, et orantes in loco isto, poenitentiam egerint nomini tuo, et a peccatis suis conversi fuerint propter aflictionem suam: exaudi eos in caelo, et dimitte peccata servorum tuorum, et populi tui Israel: et ostende eis viam bonam per quam ambulent, et da pluviam super terram tuam, quam dedisti populo tuo in possesionem.

Fames si oborta fuerit in terra, aut pestilentia, aut corruptus aer, aut aerugo, aut locusta, vel rubigo, et afflixerit eum inimicus eius portas obsidens, omnis plaga, universa infirmitas, cuncta devotatio et imprecatio, quae aciderit omni homini de populo tuo Israel: si quis cognoverit plagam cordis sui, et expanderit manos suas in domo hac, tu exaudies in caelo in loco habitationis tuae, et repropitiaberis, et facies ut des unicuique secundum omnes vias suas, sicut videris cor eius (quia tu nosti soluscor omnium filiorum hominum)ut timeant cunctis diebus, quibus vivunt super faciem terrae, quam dedisti patribus nostris.

Insuper et alienigena, qui non est de populo tuo Israel, cum venerit de terra longinqua propter nomen tuum (audietur enim nomen tuum magnum, et manus tua fortis et bracchium tuum extentum ubique) cum venerit ergo, et oraverit in hoc loco, tu exaudies in caelo, in firmamento habitaculi tui, et facies omnia pro quibus invocaverit te alienigena: ut discant universi populi terrarum nomen tuum timere, sicut populus tuus Israel, et probent quia nomen tuum invocatum est super domum hanc, quam edificavi.

Si egressus fuerit populus tuus ad bellum contra inimicos suos, per viam, quocumque miseris eos, orabunt te contra viam civitatis, quam elegisti, et contra domum, quam edificavi nomini tuo, et exaudies in caelo orationes eorum, et preces eorum, et facies iudicium eorum.

Quod si peccaverint tibi (non est enim homo qui non peccet) et iratus tradideris eius inimicis suis, et captivi ducti fuerint in terram inimicorum longe vel prope, et egerint poenitentiam in corde suo in loco captivitatis, et conversi deprecati te fuerint in captivitate sua, dicentes: Peccavimus, inique egimus, impie gessimus: et reversi fuerint ad te in universo corde suo, et tota anima sua in terra inimicorum suorum, ad quam captivi ducti fuerint: et oraverint te contra viam terrae suae, quam dedisti patribus eorum, et civitatis quam elegisti, et templi quod edificavi nomini tuo: exaudies in caelo, in firmamento solii tui, orationes eorum, et preces eorum, et facies iudicium eorum: et propitiaberis populo tuo qui peccavit tibi, et omnibus iniquitatibus eorum, quibus praevaricati sunt in te: et dabis misericordiam coram eis qui eos captivos habuerint, ut misereantur eis. Populus enim tuus est, et haereditas tua, quos eduxisti de terra Aegypti, de medio fornacis ferreae. Ut sint oculi tui aperti ad deprecationem servi tui, et populi tui Israel, et exaudias eos in universis pro quibus invocaverint te. Tu enim separasti eos tibi in haereditatem de universis

I La versión que transcribimos procede de la edición de la Biblia Sacra iuxta Vulgatam Clementinam llevada a cabo por A. Colunga y L. Turrado, Editorial Católica, Biblioteca de Autores Cristianos, Madrid, 1985 (8 $8^{\mathrm{a}}$ editio). 
populis terrae, sicut locutus es per Moysen servum tuum, quando eduxisti patres nostros de Aegypto, Domine Deus.

\section{$2 \operatorname{Par} 6,19-42$}

Sed ad hoc tantum facta est, ut respicias orationem servi tui, et obsecrationem eius, Domine Deus meus: et audias preces, quas fundit famulus tuus coram te: ut aperias oculos tuos super domum istam diebus ac noctibus, super locum, in quo pollicitus es ut invocaretur nomen tuum, et exaudires orationem, quam servus tuus orat in eo: et exaudias preces famuli tui, et populi tui Israel. Quicumque oraverit in loco isto, exaudi de habitaculo tuo, id est, de caelis, et propitiare.

Si peccaverit quispiam in proximum suum, et iurare contra eum paratus venerit, seque maledicto constrinxerit coram altari in domo ista: tu audies de caelo, et facies iudicium servorum tuorum, ita ut reddas iniquo viam suam in caput proprium, et ulciscaris iustum, retribuens ei secundum iustitiam suam.

Si superatus fuerit populus tuus Israel ab inimicis (peccabunt enim tibi) et conversi egerint poenitentiam, et obsecraverint nomen tuum, et fuerint deprecati in loco isto, tu exaudies de caelo, et propitiare peccato populi tui Israel, et reduc eos in terram, quam dedisti eis, et patribus eorum.

Si clauso caelo pluvia non fluxerit propter peccata populi, et deprecati te fuerint in loco isto, et confessi nomini tuo, et conversi a peccatis suis, cum eos afflixeris, exaudi de caelo Domine, et dimitte peccata servis tuis et populi tui Israel, et doce eos viam bonam, per quam ingrediantur: et da pluviam terrae, quam dedisti populo tuo ad possidendum.

Fames si orta fuerit in terra et pestilentia, aerugo, et aurugo, et locusta, et bruchus, et hostes, vastatis regionibus, portas obsederint civitatis, omnisque plaga et infirmitas presserit: si quis de populo tuo Israel fuerit deprecatus, cognoscens plagam et infirmitatem suam, et expanderit manos suas in domo hac, tu exaudies de caelo, de sublimi scilicet habitaculo tuo, et propitiare, et redde unicuique secundum vias suas, quam nosti eum habere in corde suo: (tu enim solus nosti corda filiorum hominum) ut timeant te, et ambulent in viis tuis cunctis diebus, quibus vivunt super faciem terrae, quam dedisti patribus nostris.

Externum quoque, qui non est de populo tuo Israel, si venerit de terra longinqua, propter nomen tuum magnum, et propter manum tuam robustam, et brachium tuum extentum, et adoraverit in loco isto, tu exaudies de caelo firmissimo habitaculo tuo, et facies cuncta, pro quibus invocaverit te ille peregrinus: ut sciant omnes populi terrae nomen tuum, et timeant te sicut populus tuus Israel, et cognoscant, quia nomen tuum invocatum est super domum hanc, quam aedificavi.

Si egressus fuerit populus tuus ad bellum contra adversarios suos per viam in qua miseris eos, adorabunt te contra viam, in qua civitas haec est, quam elegisti, et domus, quam edificavi nomini tuo: tu exaudies de caelo preces eorum, et obsecrationem, et ulciscaris.

Si autem peccaverint tibi (neque enim est homo, qui non peccet) et iratus fueris eis, et tradideris hostibus, et captivos duxerint eos in terram longinquam, vel certe quae iuxta est, et conversi in corde suo in terra, ad quam captivi ducti fuerant, egerint poenitentiam, et deprecati te fuerint in terra captivitatis suae, dicentes: Peccavimus, inique fecimus, iniuste egimus, et reversi fuerint ad te in toto corde suo, et in tota anima sua, in terra captivitatis suae, ad quam ducti sunt, adorabunt te contra viam terrae suae, quam dedisti patribus eorum, et urbis, quam elegisti, et domus quam edificavi nomini tuo: tu exaudies de caelo, hoc est, de firmo habitaculo tuo preces eorum, et facias iudicium, et dimittas populo tuo, quamvis peccatori: tu es enim Deus meus: aperiantur, quaeso, oculi tui, et aures tuae intentae sint ad orationem, quae fit in loco isto. Nunc igitur consurge Dominus Deus in requiem tuam, tu et archa fortitudinis tuae: sacerdotes tui Domine Deus induantur salutem, et sancti tui laetentur in bonis. Domine Deus, ne averteris faciem christi tui: memento misericordiarum David servi tui ${ }^{2}$.

2 No podemos abordar el complejo problema de la recensión de la Vulgata hispánica que pudo ser empleado por los redactores de la inscripción. Vid. en general, Ayuso Marazuela, 1953 y 1956, y Weber, 1945. No obstante, la comparación entre el texto de la 
Un eco de este tenor se encuentra en otra oración atribuida a Salomón, esta vez en el Libro de la Sabiduría (9, 8-10):

Et dixisti me aedificare templum in monte sancto tuo, et in civitate habitationis tuae altare, similitudinem tabernaculi sancti tui quod praeparsti ab initio (...) Mitte illam (sapientiam) de caelis sanctis tuis, et a sede magnitudinis tuae.

La perícopa 2 Par. 6, I3-2I, constituye la denominada Oratio Salomonis, situada en todos los manuscritos bíblicos latinos anteriores al siglo IX al final del libro del Eclesiástico, antes del explicit de este libro. Se trata de una adición de las versiones latinas, pues no figura en ninguno de los códices griegos (AYUSO MARAZUELA, 1956: I05; WEBER, 1945: XI-XIV, XLIV-XLVI). Desde al menos el siglo $\mathrm{VI}$ se recitaba en las rogativas anteriores a la fiesta de la Ascensión, introducidas como práctica litúrgica a fines del V (RIGHETTI, 1955: I, 850-853). Así lo atestigua el siguiente texto de Gregorio de Tours (Liber Vitae Patrum, IV. De Sancto Quintiano):

Porro in Arverno quodam tempore cum magna siccitas cuncta consumeret, et arentibus habis, nulla penitus iumentis pabula permanerent, et sancta dei rogationes illas, quae ante ascensionem dominicam aguntur, devotissime celebrarent, die tertia, cum iam portam civitatis adpropinquarent, suggerunt ei, ut ipse antephonam dignaretur imponere, dicentes: "si tu, beate pontifex, devote antephonam imposueris, confidimus de sanctitate tua, quod protinus nobis Dominus plubiam dignabitur benigne pietate largire". At ille, prostratus super cilicium suum, in ipsa platea diutissime cum fletu oravit. Exsurgens autem, antephonam quam petebant, ut virtus fuit, imposuit; verba autem eius ex illa salomonicae orationis edita haec erant: "Si clauso caelo..." (KRUSCH, 1969: 226).

De igual modo, el texto 3 Reg 8, 4-49 figura citado en el tratado De Institutione regia de Jonás de Orléans, fechado hacia 830-83I (cap $\mathrm{XV}$ ), como apoyo a la tesis enunciada en dicho capítulo, sobre la conveniencia de orar en otros lugares adecuados, si el templo se encontrase lejos (REVIRON, 1930; 189). Quizás resulte significativo, a este respecto, que la referencia a la oración de consagración del Templo por excelencia se aplique en un capítulo que trata sobre la conveniencia de orar aun fuera del templo. No sería extraño que un pensamiento similar hubiese guiado al autor de la inscripción de Naranco, edificio del que se desconoce toda epigrafía de consagración canónica, con mención del obispo consagrante y la deposición de las pertinentes reliquias.

La misma expresión se encuentra en el salmo 19, 7, dedicado específicamente a la oración pro rege ante bellum:

Impleat Dominus omnes petitiones tuas;

Nunc cognovit quoniam salvum fecit Dominus christum suum.

Exaudiet illum de caelo sancto suo,

in potentatibus salus dexterae eius.

La liturgia hispánica prescribió la lectura de 3 Reg 8, 34-40 en los días de letanías anteriores a la Ascensión: se trata de la lectio de letanias canonicas legenda per duabus vicibus in diebus letaniarum canonicarum: lectiones pro sterilitate plubie legendum ad tertia (PÉREZ DE URBEL Y GONZÁLEZ RUIZ -ZORRILLA, 1950- I955: II, 509-5 I0).

Asimismo, se inspiró en estos textos en los ordines relativos a la dedicación de iglesias y al sufragio en favor de la monarquía. Así, en el ya citado Ordo de dedicatione baselice, parte de cuyas fórmulas se contienen en el Antifonario legionense.

Officium de letanias apostolicas. Ad nona (In Paralipomenon).

Exaudi de coelo domine et dimitte peccata servis tuis et populo tuo.

Officium de sacratione baselice. Ad matutinum. Exaudi de coelo domine et dimitte peccata popu10 tuo.

Vetus latina de II Crón, 6, 13-42 (WEBER, 1945: II-15) y el de la Vulgata en lo que se refiere a la oratio Salomonis permite concluir que el redactor de la inscripción de Naranco se inspiró en la versión de San Jerónimo, dado que el texto de la Vetus no contiene el verbo dimittere, empleado en la inscripción ovetense. 
Officium de sacratione baselice. Ad matutinum Ut hedificarem (Salomon) templum in monte sancto tuo et nunc hedificabi in loco habitationis tue aram.

Officium de sacratione baselice. Ad matutinum Orantes in loco isto exaudi de coelo deus et dimitte peccata populo tuo et da pacem in terra. Officium de sacratione baselice. Ad matutinum De Sanctuario tuo domine respice alleluia de excelso caelorum habitaculo alleluia alleluia alleluia (BROU-VIVES, I959: 341, 433, 434, 437).

También, el Liber Ordinum Episcopalis (Cód. Madrid, Acad. Hist. Aem. 56):

49. Ordo pro solo rege. PSLM.

Tribuat tibi dominus secundum cor tuum et omnium consilium tuum confirmet. VR. Impleat dominus omnes petitiones tuas mittat tibi auxilium de sancto et de syon tueatur te. (JANINI, 1991: 373, n 1499).

Por último, los mismos versículos del salmo 19 inspiraron la siguiente colecta sálmica:

Imple, Domine, omnes petitiones nostras, ac mitte nobis auxilium de sancto; memor esto omnis sacrificii nostri, quod tibi, non solum oblatione, sed etiam oratione atque afflictione dicamus; ut tibi humiles semper facias, et contritos adtendas (PINELL, 1972: 62, n² 218).

Esta colecta era recitada en el oficio de la $\checkmark$ feria post Epifania, en la II feria de la $3^{a}$ semana de Cuaresma, ad matutinum, en la IV feria In capite leiunii y en un ordo de Pluralis del Liber Ordinum (Cód. Madrid, Acad. Hist. Aem. 56) ${ }^{3}$ (PINELL, 1972: 189, 195, 205, 235) ${ }^{4}$.

La respuesta divina a la petición inspirada en el salmo 19 -que se recoge en el ordo 49 del Liber Ordinum- se encuentra en el Sacrifi- cium u oración equivalente al ofertorio de la misa de dedicación, tal y como figura en el Antifonario legionense:

Aliud sacrificium. Aedificavit Salomon domum nomini Domini Dei Israhel, et posuit ibi archam in qua est testamentum ipsius, cum universis que sanctificata erant deo, alleluia. I. -Levaverunt sacerdotes archam et omnia vasa templi; et ingredientes templum, intulerunt sacerdotes archam in locum suum, in conspectu Domini, in sancta sanctorum. II. -Loquutus est Dominus ad principem, dicens: audivi orationem tuam et precem tuam qua deprecatus es in conspectu meo; et feci tibi secundum petitionem tuam, et sanctificabi domum hanc, quam haedificasti; ponam nomen meum ibi in sempiternum; et intulit princeps sancta in sanctuariis Dei (PRADO, 1926: 162-163).

Es de destacar que el citado ordo y el siguiente -missa pro solo rege dicenda -reproducen los textos del ordo XII Missa votiba de rege, recogido en el mismo Liber Ordinum (Cód. Sil. 4, segunda parte), donde se ruega por la pareja real, solicitando la aceptación de sus dones e implorando la benéfica acción divina en su favor. En tres de los textos ( $n^{\circ} 666,668$ y 67l) se aplica al príncipe y a la pareja el calificativo de gloriosus, que figura igualmente en la inscripción del altar, y cuya presencia motivó la aparición de alguna duda sobre la genuinidad de tal inscripción. Al menos conocemos en la Hispania visigoda cuatro inscripciones consecratorias en las que la datación por el año del reinado incluye el mismo calificativo: una iglesia dedicada a Santa María en Toledo, en 587, otros dos templos, en honor de San Vicente y de San Esteban, en la diócesis de Guadix, en 594 y 607, respectivamente y un último ejemplo perteneciente a Bailén, en 691 (CANELLAS LÓPEZ, 1979: 138, 143, 177, 247). El mismo epíteto es prerrogativa de los todos los soberanos altomedievales, respondiendo por

\footnotetext{
3 Pinell, (1972: 62), señala la presencia de esta colecta en el n 330 de la edición del Liber Ordinum debida a Marius Férotin. La más reciente edición del mismo texto, debida a José Janini ( $|99|$ ) no la recoge.

4 Salvo esta última mención, perteneciente a la tradición A -tarraconense-toledana- de la liturgia hispánica, las otras tres pertenecen al Breviarium Gothicum toledano, representante de la tradición B -bética-. La mención del Liber Ordinum es tardía, pues se inserta en un apéndice de misas votivas, a modo de sustitutivo de la oratio post gloriam romana, lo que, en opinión de Pinell, es signo de influjo romano fechable a fines del IX o a lo largo del X (PINELL, 1972: 264). La colecta fue recogida en la colección carolingia (Cód. Oxford, Bodl., D'Orville, 45, proc: Moissac, 1025), con ciertas modificaciones (PINELL, 1972: 263).
} 
ello su empleo a la normalidad de los usos diplomáticos de la época ${ }^{5}$.
En los sacramentarios francos del siglo VIII

(Gellone, Autun, Angoulême), por el contra-

5 Los monarcas visigodos disfrutan sistemáticamente de él en las alusiones que se les dedican en las actas de los concilios toledanos: anno regnante quarto gloriosissimo atque piisimo et Deo fidelissimo domno Reccaredo rege (Concilio III, 589); gloriosissimus domnus noster Reccaredus rex (Concilio III, 589); gloriosissimus et piissimus domnus noster Reccaredus rex (Concilio III, 589); anno tertio regnante domno nostro gloriosissimo principe Sisenando (Concilio IV, 633); gloriosissimum domnum nostrum Sisenandum regem (Concilio IV, 633); gloriosi principis nostri Chintilani regis (Concilio V, 636); excellentissimo et glorioso principi nostro Chintilae regi (Concilio V, 636); orthodoxi et gloriosi Chintilano regis (Concilio VI, 638); excellentissimi et gloriosi principis Chintilani regis (Concilio Vl, 638); christianissimo et gloriosissimo Chintilani principi nostro (Concilio VI, 638); immortali Deo et glorioso Chindasvinto principi (Concilio VII, 64I); anno quinto orthodoxi atque gloriosi et vera clementiae dignitate praespicui Recesuinti regis (Concilio VIII, 653); serenissimus princeps pia religione plenissimus et summo laudum titulo gloriosus (Concilio VIII, 653); in gloriosi principis potestate (Concilio VIII, 653); super serenissimum Recesuintum principem gloriosum (Concilio VIII, 653); cum glorioso domino nostro Recesuinto rege (Concilio VIII, 653); lex edita in eodem concilio a Recesuinto principe glorioso (Concilio VIII, 653); anno septimo Reccesuinti gloriosissimi principis (Concilio VIIII, 655); anno octavo gloriosi domni et religiosissimi Recesuinti principis (Concilio X, 656); gratias invisibili Deo et glorioso rerum domino Recesuinto regi (Concilio X, 656); gloriosissimi Recesuinti principis inhaerente voluntate religiosa (Concilio X, 656) (MARTíNEZ DíEZ Y RODRÍGUEZ, I992: $49,99,179,255,277,287,296,323,329,357,36,402,435,456,457,517$ ), a lo que se suma lo ya recogido el el trabajo repetidas veces citado (GARCÍA DE CASTRO VALDÉS, I995: I I5, n. 438; KING, I98I: 43-49; STROHEKER, 1965: 230-232). El título fue asignado por Isidoro a los reyes visigodos católicos, Recaredo y Suínthila (Historiae Gothorum, 5I, 52, 62) (RODRÍGUEZ ALONSO, 1975: 260, 264), y fue empleado por Cesarius al encabezar una de sus epístolas al rey Sisebuto -Domino gloriosissimo adque clementissimo domno Sisebuto regi- (GIL, 1991:6). La renovación del ideario neogótico desde el reinado de Sancho I el Craso de León devuelve vitalidad a la fórmula (ISLA FREZ, 1998: 8I-82). La correspondencia con los monarcas merovingios permite documentar su uso entre las cancillerías regias. Así, la reina Brunechildis y el rey Childeberto II se dirigen a Atanagildo en sendas misivas de 584, encabezándolas respectivamente por las fórmulas Domino glorioso atque ineffabili desiderio nominando ... Athanagildo regi, y Domino glorioisimo et ubique praecelsus ... Athanagildo regi (DUMMLER-GUNDLACH, 1994: 139-140). El mismo tratamiento se refleja en la correspondencia de los merovingios con el emperador bizantino. Así, Childeberto I se dirige a Mauricio en 584 con la fórmula Domino glorioso, pio, perpetuo, inclito, triumphatore ac semper augusto, patri, Mauricio imperatori, que reproduce también la carta de Brunechildis al mismo Mauricio (DÜMMLER-GUNDLACH, 1994: I38-139). Los sucesores carolingios y los papas mantuvieron el título en la actividad diplomática con los emperadores orientales. Así, Carlomagno se dirigió a Miguel I (8I3) como dilecto et honorabili fratri Michaeli glorioso imperatori et augusto (DÜMMLER, 1994: 556), y Nicolás I a Miguel III (860) como dilecto filio Michaeli glorioso imperatori graecorum (DÜMMLER-PERELS, 1995: 433).

No faltan testimonios de su aplicación en la liturgia regia: en el Ordo de susceptione regis quando de vicino regreditur, recogido en el Liber ordinum episcopalis ( $n^{\circ} 291$ ), se implora la bendición divina sobre el monarca en estos términos:

Ingressum gloriosi principis nostri ill. ubertate benedictionis tue perlustra... (JANINI CUESTA, I99I: I49). A lo que se pueden añadir diversos lugares extraídos de las misas votivas de rege, recogidas en el mismo libro:

n 666: Offerentes gloriosi principis votiba munera... Tribuens ei cum gloriosa coniuge

$n^{\circ}$ 668: Ut gloriosum principem nostrum ill regem...

n 67I: Deus pater omnipotens qui es rex regum et dominus omnium potestatum, ad hec vota gloriosi principis... (JANINI CUESTA, I99 I: 234-237)

La fórmula pasó al redactor de la versio ad Sebastianum de la Crónica de Alfonso III, donde aparece aplicada a Wamba, en la dedicatoria inicial de la obra, y al propio rey leonés García, hijo de Alfonso III (Chronica Adefonsi III, la; GIL et al, I985: I I5). Las dos redacciones, pelagiana y silense, de la crónica de Sampiro de Astorga califican de gloriosissimus rex a Alfonso III en el relato de la batalla de Polvoraria (PÉREZ DE URBEL, 1952: 283). Ocasionalmente aflora su empleo en la documentación diplomática asturleonesa: en el pacto monástico fundacional de San Miguel de Pedroso (24 de abril de 759), se hace mención del gloriosus Froilanus rex (FLORIANO CUMBREÑO, 1949-50: I, 59). Un siglo después, el abad Reterico encabezaba una donación a Alfonso III con la fórmula tibi gloriosissimo principi nostro Adefonso (ID, 1949-50: II, 65).

Igualmente, los monarcas merovingios y carolingios se atribuyeron sistemáticamente el calificativo en los sellos de rubricación de los documentos emitidos en su nombre. Pipino, Carlomán y Carlomagno emplearon sistemáticamente las fórmulas Signum Pippini gloriosissimi regis, Signum Pippini gloriosi regis, Signum domno nostro Pippino gloriosisimo rege, Signum Carolomanno gloriosissimo rege, Signum Caroli gloriosissimi regis, fórmulas que no fueron abandonadas tras la coronación imperial de este último en 800 , adoptando a partir de entonces las siguientes: Signum Karoli piissimi ac serenissimi imperatoris, Signum Caroli gloriosissimi imperatoris, Signum Karoli piissimi ac serenissimi imperatoris (MÜHLBACHER, I991: passim). Los sucesores, Ludovico Pío, Carlos el Calvo, Odón, Carlos el Simple, Luis IV, continuaron con el uso en los siglos IX y X: los diplomas concedidos a los hispani del Pirineo oriental mantienen la fórmula signum Ludowici gloriosissimi imperatoris, signum Karoli gloriosissimi regis, a la vez que repiten el epíteto en la data -regnante $N$ gloriosissimo rege- (ABADAL I DE VINYALS, 1952: passim; UDINA MARTORELL, I95I: passim). Se documenta su empleo igualmente en los diplomas de Lotario I: Signum Hlotarii gloriosissimi imperatoris, Signum Hlotarii gloriosissimi augusti, Signum Hlotarii serenissimi augusti, Signum Hlotarii serenissimi imperatoris, y Lotario II: Signum Lotharii gloriosi regis, Signum Hlotharii gloriosissimi regis, Signum Hlotarii serenissimi regis (SCHIEFFER, 1995: passim). Por su parte, la correspondencia de los monarcas merovingios revela el uso habitual del epíteto, como atestiguan los encabezamientos de las siguientes misivas: del obispo Aureliano de Arles a Teudeberto I (546-548), Domino inclito et ubique gloriosissimo adque in Christo piisimo domno et filio Teudeberto regi; de Desiderio de Cahors a Sigeberto III (post 639), Domino gloriosissimo, triumphali palmate coronato ... Sigeberto regi (DÜMMLER-GUNDLACH, I994: I24, I94195). Por último, la correspondencia papal confirió el mismo tratamiento a los monarcas coetáneos, desde tiempos merovingios: Bonifacio IV a Theodorico II (6I3), Domino gloriosissimo atque praecellentissimo filio Theodorico regi francorum (DÜMMLER-GUND$\mathrm{LACH}$, 1994: 455-456). La costumbre prosiguió en la correspondencia dirigida a los carolingios desde el inicio de la dinastía, como atestiguan las misivas de Gregorio II a Carlos Martel (722-723), encabezada por Domino glorioso filio Karolo duci (DÜMMLER-GUNDLACH, 1994: 269); de Nicolás I a Carlos el Calvo (860), Karolo glorioso regi spiritali filio nostro; del mismo pontífice a Horic de Dinamarca, en cuya correspondencia se alude a Luis el Germánico como filio nostro glorioso rege Hludowico; de Hadriano II al mismo monarca (868), Dilecto filio Karolo glorioso regi (DÜMMLER-PERELS, 1995: 268, 293, 704); y de Juan VIII y Esteban $\vee$ a los diversos soberanos de una Europa cada vez más fragmentada, Luis el Germánico, Carlos el Calvo, Luis el Tartamudo, Carlos el Gordo y 
rio, no se observa tan directa inspiración del rito de dedicación de templos en ambas lecciones bíblicas. Pese a ello, puede señalarse la siguiente fórmula, recogida en la oración consecratoria del rito De Dedicatione Basilice:

Exaudi preces servorum tuorum ... in hoc habitaculo tuo supplicantes Deus protege, dignanter exaudi ... (Liber Sacramentorum gellonensis, $n^{\circ}$ 2426, DUMAS, 1981: 362-363; Liber Sacramentorum augustodunensis, $n^{\circ}$ | 453, HEIMING, 1984: 168).

También, en la Missa de dedicatione aecclesiae, los tres sacramentarios incorporan una cita de 3 Reg, 8, 29:

ut sint oculi tui aperti super domum istam die ac nocte (Liber Sacramentorum gellonensis, $n^{\circ}$, 2454, DUMAS, 1981: 371 ; Liber Sacramentorum augustodunensis, $n^{\circ}$ 1491; HEIMING, 1984: I 75; Liber Sacramentorum engolismensis, $n^{\circ} 2133$, SAINT ROCH, 1987: 329).

\section{LAUDES Y LETANIAS}

Existe una relación estrecha -puesta de manifiesto por Kantorowicz hace ya más de cincuenta años- entre las preces litánicas peniten- ciales, inspiradas en la oración de Salomón que acabamos de citar, y las laudes regiae, letanías litúrgicas de alabanza de los monarcas francos, en cuyo favor se invocaba la ayuda de toda la corte celestial (KANTOROWICZ, 1942, 1946). El origen de esta práctica está enraizada en el ceremonial imperial romano, que progresivamente fue desarrollando aclamaciones colectivas al príncipe, practicadas en los juegos, en las entradas en las ciudades, en la curia, hasta el surgimiento de coros litánicos expresamente dedicados a la alabanza del soberano y la generalización de la aclamación senatorial, inicialmente concebida como simple forma de adlación y finalmente incorporada protocolariamente en los acta Senati tras las orationes principum (ALFÖLDI, 1980: 79-88). El uso de la aclamación solemne del emperador pervivió en el Imperio oriental en las sesiones conciliares (SCHRAMM, 1984: 4I). En Hispania hay ostensibles testimonios de esta aclamación monárquico-litúrgica en las actas del III Concilio Toledano (589) ${ }^{6}$ : tras la confesión de fe católica de Recaredo y su esposa Baddo, el conjunto de la asamblea aclamó sus personas en los siguientes términos:

I Gloria Deo Patri et Filio et Spiritui Sancto, cui cura est pacem et unitatem ecclesiae suae sanctae catholicae providere.

\footnotetext{
Swatopluk-Zwentipold de Moravia, apreciándose la particularidad de que el epíteto se hace extensivo a los condes cuasi autónomos de la península itálica, Berengario de Friul, Suppo, Pandenulfo de Capua y Gaiferio de Salerno, así como a Boso de Provenza, todos intitulados gloriosi (CASPAR-LAEHR, I993: 2, 19-20, 82, 99, I01, 106, I41, 192, 197, 222, 340). La mayoría de los corresponsales laicos y eclesiásticos con monarcas carolingios mantienen el tratamiento: Magno de Sens y sus sufragáneos a Carlomagno (809-8I2) -gloriosissimo imperatori-, Maxentius de Aquilea a Carlomagno (8II-8I2) -piissimo ac christianissimo gloriosoque principi a Deo coronato et conservato... domno Carolo-, Leudrad de Lyon a Carlomagno (809-812) -Domno christianissimo et gloriosissimo Carolo imperatori...-, Claudio de Turín a Ludovico Pío (816) -proprio domino meo inclito atque glorioso... Hlodoico- (DÜMMLER, 1994: 534, 537, 539, 556, 597), Agobardo de Lyon a Ludovico Pío (816) -Christianorum religiosissimo ... domno gloriosissimo Hludowico imperatori-, Amalario de Tréveris a Carlomagno (8I I-8I2) -gloriosissimo atque excellentissimo augusto a Deo coronato Karolo serenissimo-, Rabano Mauro a Ludovico Pío (834-838) -Domino gloriosissimo et gratia Dei plerissimo ... Hludowico regi-, Angelomus de Luxeuil a Lothario (85 I-852) -gloriosissimo atque praestantissimo imperatori Domino Lothario- (DÜMMLER-HAMPE, 1995: I53, I85, 243, 422, 625), Hincmar de Reims a Carlos el Calvo (856-858) -domino glorioso regi Karolo-, Hincmar de reims a Luis el Germánico (865) domino Hludowico regi glorioso- (PERELS, I985: 44, 52, 167-172), Lupo de Ferrières a Carlos el Calvo (850-85I) -domino glorioso regi Karolo-, Ratramnus de Corbie a Carlos el Calvo (850) -domino glorioso atque praecellentissimo principi-, Johannes Scotto a Carlos el Calvo (858-860) -gloriosisimo catholicorum regum- (DÜMMLER-PERELS, 1995: I I I, I49- I50, I58), Anastasio el bibliotecario a Carlos el Calvo (875) -domino gloriosissimo et magno principi Karolo- (CASPAR-LAEHR, 1993: 434).

No falta tampoco el empleo en la Britania anglosajona, como atestigua Beda (Historia ecclesiastica gentis anglorum, praefatio; SPITZBART, 1997: 16), en la misma dedicatoria de la obra gloriosisimo regi Ceoluulfo, repitiéndose el uso del adjetivo en las transcripciones de las cartas papales a los monarcas anglosajones que el mismo autor incluye en la obra: Domino gloriosissimo atque praecellentissimo filio Aedilbercto regi Anglorum; Viro glorioso Eduino regi Anglorum; Dominae gloriosae filiae Aedilbergae reginae, así como en sendas referencias a Pipino, gloriosisimus dux Francorum, y al rey de los Pictos Nechtan, excellentissimo et gloriosissimo regi, según la dedicatoria de la epístola que le dirigió el abad Ceolfrith (SPITZBART, 1997: II4, I64, 170, 460, 506). Aello se suman ejemplos extraídos de correspondencia mantenida entre abades y monarcas, como la de Aldhelm de Malmesbury a Geraint de Dumnonia (675705), que emplea la fórmula Domino gloriosissimo occidentalis regni sceptra gubernanti ... Geruntio regi (DÜMMLER-GUNDLACH, I994: 23I), o la de Eanwulf a Carlomagno (773), encabezada por Domino gloriosissimo atque praecellentissimo Ceorlo regi Francorum (DÜMMLER-GUNDLACH, 1994: 409).

6 Curiosamente no tenidos en cuenta por Kantorowicz, como en su momento hizo notar Barbero de Aguilera (1985: 107-1। I).
} 
Il Gloria Domino nostro lesu Christo, qui pretio sanguinis sui ecclesiam catholicam ex omnibus gentibus congregavit.

III Gloria Domino nostro lesu Christo, qui tam illustrem gentem unitati verae fidei copulavit et unum gregem et unum pastorem instituit.

IV Cui a Deo aeternum meritum nisi vero catholico Reccaredo regi?

$\checkmark$ Cui a Deo aeterna corona nisi vero orthodoxo Reccaredo regi?

VI Cui praesens gloria aeterna nisi vero amatori Deo Reccaredo regi?

VII Ipse novarum plebium in ecclesia catholica conquisitor.

VIII Ipse mereatur veraciter apostolicum meritum, qui apostolicum implevit officium.

VIIII Ipse sit Deo et hominibus amabilis, qui tam mirabiliter Deum glorificavit in terris.

Praestante Domino nostro lesu Christo, qui cum Deo Patre uiuit et regnat in unitate Spiritus Sancti in saecula saeculorum. Amen (MARTÍNEZ DÍEZ Y RODRÍGUEZ, 1992: 73-74).

Las actas de concilios posteriores recogen el hecho de la rendición de gracias al monarca, aun cuando no transmitan el texto de tales agradecimientos. La ceremonia debió de revestir carácter aclamatorio, como de desprende de la propia rúbrica del canon conciliar correspondiente. Así, consta en el Concilio V, canon VIIII, De favore principis concilii acclamatione concesso.

Post haec $<$ Domino gratias reddere $>$ gratias excellentissimo et glorioso principe nostro Chintilae peragimus, cuius ardor fidei et studio bonae intentionis et unanimitatis concordiam nobis tribuit et fiduciam caritatis. Donet ei Dominus et de inimicis triumphum et de beatitudine gaudium, custodiat eum protectione assidua et muniat bonae voluntatis suae circuminspectione tutissima, cuius regnum manet in saecula saeculorum. Amen (MARTÍNEZ DÍEZ Y RODRÍGUEZ, 1992: 287).

La práctica pervivió en los concilios subsiguientes: al mismo Chintila le fueron rendidas gracias en el VI, a Chindasvinto en el VII y a Recesvinto en los VIII y VIIIII (MARTÍNEZ DíEZ Y RODRÍGUEZ, 1992: 329, 356, 436, 510-5।I). En el imperio bizantino hay testimonios de la aclamación al emperador Constantino IV por los padres conciliares en el VI Concilio ecuméni- co (Constantinopla, 68I) (OSTROGORSKY, 1984: 138-139). No faltan investigadores que han vinculado genéticamente las laudes regiae en honor de Pipino y Carlomagno con las aclamaciones hispanas. En los cantos francos, la alabanza al Papa va seguida de invocaciones a los apóstoles, la del monarca, de invocaciones a los ángeles, y la del ejército, de la de los mártires, orden inspirado en el que en las aclamaciones hispánicas correspondía a la Trinidad: Padre y ángeles, Hijo y apóstoles, Espíritu Santo y mártires. De este modo, sacerdocio y realeza correspondían respectivamente a los órdenes de la Creación y de la Redención (KANTOROWICZ, 1995: 194; EWIG, 1987: 78; FOLZ, 1989: |17-118).

El contenido de estas laudes hispanicae está en consonancia con la aclamación a Carlomagno proferida por el Concilio de Frankfurt (794) -Sit rex et sacerdos! Sit omnium christianorum moderatissimus gubernator!- (KANTOROWICZ, 1942<1995>: 198), en la que se ha apreciado el directo préstamo de la fórmula bizantina basileús kai hiereús (FOLZ, 1953: 26), y con la proferida por los asistentes a su coronación como emperador en la Navidad de 800 -Carolo augusto, a Deo coronato, magno et pacifico imperatori romanorum, vita et victoria!- (HALPHEN, 1968: । 18; FOLZ, 1989: 197-202). Al soberano se le tributan alabanzas, pronunciando la asamblea votos por su futuro. En los restantes laudes, fechados avanzado el siglo IX y en siglos posteriores, las laudes imploran la ayuda divina en favor del soberano, el romano pontífice, el obispo local y el ejército, alternando la petición con una letanía de alabanza a Cristo (HALPHEN, 1968: 183-194). La actitud ante el poder terreno en ambos casos no puede ser más diferente: en los primeros textos, la asamblea conciliar actúa como espejo que refleja la gloria del monarca; en los segundos, el poder civil es simple objeto de la atención de la asamblea, en una plegaria litúrgica de alcance general. De hecho, en la víspera de la coronación imperial de Ludovico Pío en Reims, a cargo del papa Esteban III (8I6), la comitiva papal fue recibida por el monarca con triple postración, tras lo cual, según el testimonio de Thegan en la Vita Ludowici Imperatoris ( I6),

Amplexantes enim se et osculantes pacifice perrexerunt ad ecclesiam; qui cum diu orarent, 
erexit se pontifex, et excelsa vice cum clero suo fecit ei laudes regales (PERTZ, 1925a: 594),

testimonio que corrobora la anónima Vita Hludowici Imperatoris (26):

Quo finito ymno <Te Deum>, laudes imperatori debitas clerus concinabit romanus, quorum finem apostolicus domnus oratione complevit (PERTZ, 1925a: 620).

Se obtiene de este modo la impresión de que las laudes han sido ya plenamente incluidos en la liturgia común en esta fecha. A su canto precedió la proskynesis del futuro emperador ante el papa, quien fue el encargado de concluir la oración litánica. Precisamente en esta ceremonia se repitió el rito del officium stratoris, por el cual el monarca conducía la montura del pontífice llevándola de la brida, gesto repetido en 858 por Luis II ante Nicolás I (HACK, 1999: 28). Sin embargo, la tradición documental, según la cual este rito habría sido inaugurado como procedimiento diplomático por Pipino ante Esteban II, en 754, gesto que fue aprovechado e incorporado al texto por el redactor del Constitutum Constantini (FOLZ, 1953: 20), ha despertado dudas sobre su autenticidad en la reciente investigación (HACK, 1999: 20), por lo que es preferible prescindir de este hipotético antecedente a la hora de valorar la ceremonia.

En cualquier caso, la actitud de Ludovico Pío en la fecha que comentamos no se diferencia a grandes rasgos del ordo desarrollado en los encuentros entre papas y emperadores en la primera mitad del IX (León III y Carlomagno en Paderborn 799 y Reims 804; Esteban IV y Ludovico Pío en Reims 816; Gregorio IV y Ludovico Pío en Rotfeld 833; Nicolás I y Luis || de Italia en Quinto 858), sometidos a una rígida serie de actos ritualizados, en los que se desenvuelven las tres fases del acontecimiento, adventus, occursio y deductio. El primer encuentro, al fin de la occursio, está encuadrado por gestos de humillación del monarca ante el pontífice: repetidas prostraciones, finalizadas con el beso de los pies, tras lo cual, el pontífice levanta al monarca, lo abraza e intercambia con él el beso de la paz (HACK, 1999: 20-2I). Con ello, el anfitrión demuestra su reconocimiento a la dignidad del huésped, quien, recíproca- mente, habrá de repetir la misma actitud cuando su anfitrión se convierta en visitante, tal y como ocurrió en el encuentro de León III y Carlomagno en Roma en 800 (IBIDEM, 28-3I).

\section{DAVID Y SALOMÓN EN LA TEOLOGÍA POLÍTICA DEL OCCIDENTE ALTOMEDIEVAL}

Las referencias a David como modelo de monarca altomedieval arrancan de la exaltación de Heraclio tras las victorias sobre los persas y ávaros en 626-628, que condujeron a la adopción, en 629, del título de basileús, en sustitución de la fórmula imperial romana, traducida literalmente al griego y usual hasta entonces (OSTROGORSKY, 1984: I | 3-1 | 4, I 17- | 20; GIL, 1977: 33-34). León II calificó a Constantino IV (668-685) de novus David (SCHRAMM, 1963: 235). En Occidente, se conocen textos coetáneos que proponen las figuras de ambos personajes bíblicos como espejo de príncipes. Así, una epístola de un obispo anónimo dirigida a un joven rey merovingio -Clodoveo II o Sigeberto III-, fechada en 645, establece el código de comportamiento real a partir de las personalidades de ambos monarcas: David sabio y humilde, agradable a Dios en todas sus obras, invicto en la guerra, propulsor del templo; Salomón, constructor del mismo, recto en el juicio, sabio en su palabra; ambos pendientes en todo momento de la voz de sus profetas y en continua comunicación con Dios a través de la oración (DÜMMLER-GUNDLACH, 1993: 457-460). También, el relato de Gregorio de Tours (Liber IV historiarum, 20), referido a la rebelión de Chramno contra su padre Clotario, aunque en este caso se han apuntado para el hitoriógrafo merovingio razones de justificación teológico-moral del comportamiento del padre respeto al hijo (SCHEIBELREITER, 1999: 223):

Ibatque Clotarius rex tanquam novus David contra Absalon filium pugnaturus, pangens atque dicens: "Respice, Domine, de caelo, et iudica causam meam, quia iniuste a filio inimicus patior. Respice, Domine, et iudica iuste, illudque impone iudicium, quod quondam inter Absalonem et patrem eius David posuisti" (KRUSCH Y LEVISON, 1993: 153). 
Sin salir del mundo merovingio es preciso aludir a Clotario II, comparado a David en una exhortación del concilio de 6/4, en la que el contexto de la comparación es la idea de servicio regio al pueblo de Dios, preanuncio del concepto ministerial de la realeza tan caro a los teólogos coetáneos de Ludovico Pío (FOLZ, 1989: 36).

Por último, en la Vita Wilfridi eboracensis, se aplica la comparación a Ecgfrith de Northumbria:

lustus et sanctus regensque populos et validus sicut David in centurione hostium, humilis tamen in conspectu Dei apparens (...) semper in omnibus Deo gratias agebat (KRUSCH-LEVISON, 1979b: 215).

Sin embargo, estas menciones tempranas, precarolingias, de David en relación con los detentadores del poder civil conviven con otras en las que el objeto de comparación con el monarca bíblico es un obispo. Atestiguan esta tradición la Vita Wilfridi I episcopi eboracensis, en el capítulo en el que Alchfrid de Northumbria, hijo de Oswiu, propone a Wilfrid que permanezca a su lado:

Tunc enim mirifice anima utriusque in alterum conglutinata est, sicut animam David et lonathae in alterutrum compaginatam legimus (...). Sicut enim David puer electus a Domino est et, per Samuhelem unctus, dona prophetiae accipere post multas temptationes meruit, ita sanctus Wilfridus presbiter post multas benedictiones sanctorum Dei tam multiplices donationes coram Deo et hominibus, quam enumerare nullus potest, Deo concedente et in angustiis suis custodiente, accepit (KRUSCH-LEVISON, 1979b: 20I-202).

El mismo Wilfrid, una vez consagrado obispo, teniendo noticia de la destitución de su sede del obispo Ceadda, depuesto por el arzobispo Teodoro de Canterbury a causa de su conducta, aprecibido de que el depuesto había cumplido la correspondiente penitencia, le devolvió el cargo, secundum preceptum Domini non malum pro malo, sed bonum ut David Sauli, pro malo reddens, qui dixit: non mittam manum meam in Christum Domini (IBIDEM, 210).
El término de comparación surge nuevamente en la Vita Remigii episcopi remensis, debida a la pluma de Hincmar de Reims. En esta ocasión la similitud surge a propósio del arrepentimiento y la penitencia cumplida por el propio biografiado, que le permitió seguir en el cargo a pesar del pecado cometido:

Nam et sanctus David de criminibus mortiferis egit poenitentiam, et tamen in honore suo perstitit, et beatum Petrum quando amarissime lacrimas fudit, utique Dominum eum negasse penituit, et tamen apostolus mansit (KRUSCH, 1995: 306).

Por último, incluso la comparación fue aplicada a un simple sacerdote. La Vita Gamalberti presbyteri Michaelbuchensis incorpora la siguiente anécdota: nacido en casa noble, y habiendo rechazado la vida de las armas que proponía su padre, éste pertesus, non absque Dei nutu posuit eum pastorem suis gregibus, digna quippe ratione, ut cum David custos fieret ovium, qui cum Petro futurus erat pastor animarum (KRUSCH-LEVISON, 1979a).

De la simple observación de estos ejemplos parece desprenderse la siguiente conclusión: las referencias a David en la literatura precarolingia afectan diferenciadamente a monarcas y obispos. Para los primeros, David es espejo de virtudes militares.modelo de servicio a la Iglesia y estímulo de comportamiento en rebeliones filiales. Para los segundos, es modelo de penitencia y reconciliación. Ambos campos de la conducta moral responden a los ideales respectivos de laicos y clérigos en el ejercicio del poder.

Ahora bien, la equiparación plena entre el protomonarca hebreo y el nuevo rector de la Cristiandad tuvo lugar a raíz de la consagración real de Pipino, su esposa y sus dos hijos, llevada a cabo por el pontífice Esteban II en Saint Denis en 754 (HALPHEN, 1968: 33-34, 38-39; FOLZ, 1989: I I I I I2), quien llamó al rey de los francos novus David y novus Moyse (SCHRAMM, 1963: 236). Poco tiempo después, en 767, Paulo I se dirigía a Pipino en estos términos:

Explere verbis nequeo et penitus sermonum copia nequaquam complecti valeo, excellentissime et 
re vera prae cunctis regibus christianissime atque orthodoxe regum, quantum vestris meritis atque piis operationum studiis intima cordis nostra affectio congratulatur, dum profecto vestro certaminis praesidio et laborioso conamine sancta catholica et apostolica, universalis mater vestra spiritalis, Dei ecclesia atque orthodoxa christianorum fides ab emulorum impugnationibus erepte consistunt; et ex hoc indesinenter ab omni populo christiano redemptori nostro domino Deo ob tantum vestrum adhibitum beneficii adminiculum referuntur laudes. Unde merito, christianissime fili et spiritalis compater, cum egregio illo ac praecipuo David rege et eximio prophetarum in celestibus regnis participem te esse, omnium fidelium mentes opinantur, quia sicut honorum infulis, ita quoque et operibus eum coequare christianitas tua, ut ipsa rei operatio demonstrat, dinoscitur. Ille enim, erepta ab alliophilis arca Domini, cum ymnis et canticis spiritalibus ac psalterii modulatione exultans iocundabatur; tu quoque, fundamentum et capud omnium christianorum sanctam Romanam redimens ecclesiam et universum ei subiacentem populum, gaudens atque laetus omnipotenti domino Deo nostro offerre satagis, cuius tanti pii operis perfectionem adhibere benignitas tua anhelat; de quo iam repositam sibi in coelestibus arcibus praemiorum credat consequi remunerationem (DÜMMLER-GUNDLACH, 1994: 557).

En el mismo año, muerto Paulo I, su sucesor Constantino II renovaba la metáfora bíblica, asimilando al rey de los francos con un nuevo Moisés -utpote novum Moysen-, escogido por Dios a través de la mano de San Pedro y su vicario ad exaltandam sanctam suam ecclesiam et redimendam hanc provinciam (DÜMMLER-GUNDLACH, 1994: 649). Meses después, la petición de auxilio a Pipino por parte del pontífice incorporaba una larga disquisición sobre la predestinación del monarca franco a la defensa de la Iglesia, del mismo modo como había sido predestinado David:

Unde apertae cunctis datur intelligi, quia omnia iam ante mundi constitutionem a Deo predestinata sunt. An non erat predestinatus davit, de cuius secundum carnem Christus in mundo editus est? Pusillus enim inter fratres existens, ab ovibus patris abstultus in regem unctus est. Et quia a Deo predestinatus es defensor sancte Dei ecclesiae, ac noster adesse, exaudi preces nostras, mitissime rex (DÜMMLER-GUNDLACH, 1994: 652).

La tendencia alcanzó el ápice, de modo especial, en el tiempo inmediato a la coronación imperial de Carlomagno (800). A este último Alcuino calificaba en poemas laudatorios y epístolas de carus David, dulcissimus David, desiderantissimus David, dilectissimus David y amatus David especialmente en los años 796-800 (HALPHEN, 1968: I 15-1 16; FOLZ, 1989: 135-139; DÜMMLER, 1994: 173, 175-176, 185, 205-210, 224, 235, 237, 241, 250, 287-289, 357-358; DÜMMLER, 1978b: 257-258). En ello había sido precedido por Paulo Diácono, quien dirigió un poema al rey de los francos en los siguientes términos (Carmina, $\mathrm{XXVI}$ ):

Multa legit paucis, qui librum praedicat istum, Hoc servus fecit, Karolo rege, tuus.

Sic una ex multis nunc fiat ecclesia templis; Det David vires scilicet ipse Deus (DÜMMLER, 1978b: 62).

La exaltación de Carlomagno adoptó tonos cuasi litúrgicos en la prosa de Alcuino, en carta dirigida al mismo Carlomagno en 794-795:

Beata gens, cuius est dominus Deus eorum: et beatus populus tali rectore exaltatus et tali praedicatore munitus; et utrumque: et gladium triumphalis potentiae vibrat in dextera et catholicae praedicationis tuba resonat in lingua. Ita et David olim praecedentis populi rex a Deo electus et Deo dilectus et egregius psalmista Israheli victrici gladio undique gentes subiciens, legisque Dei eximius praedicator in populo extitit. Cuius eximia filiorum nobilitate in salute mundi, de virga flos campi et convallium floruit Christus, qui istis modo temporibus ac eiusdem nominis, virtutis et fidei David regem populo suo concessit rectorem et doctorem. Sub cuius umbra superna quiete populus requiescit christianus, et terribilis undique gentibus extat paganis. Cuius devotio a sectis perversi dogmatis fidem catholicam evangelica soliditate munire non cessat, ne quid novi et apostolicis inconveniens doctrinis per clandestinas subreptiones alicubi oboriri valeat, sed caelestis gratiae lumine fides ubique fulgeat catholica (DÜMMLER, 1994: 84), 
pues el rey de los francos unía en su persona las condiciones de gobierno y predicación que caracterizaban al de los hebreos. La identificación concluía con una triunfal aclamación versificada, alusiva a las laudes regiae, en 799:

Det tibi consilium pacis simul atque salutis,

David amor populi, Christus ubique pius;

Omnipotens cuius defendat dextera semper,

Victorem faciens, teque tuosque simul;

Nomen ut aeternum toto laudetur in orbe

Illius ex vobis, pro pietatis ope.

Aspice, cunctorum vitae spes, forma salutis

Qualiter ad vosmet tota recurrat ovans.

Qui tristis veniat, redeat iam laetus ad Urbem

Per pia dona patris consiliumque sacrum.

Quod petit inveniens, quodque speravit adeptus;

Hinc Christo laudes hymnidicas referens,

Qui mundo talem tribuit sub tempore nostro

Rectorem, sacrae regmine iustitiae (DÜMMLER, 1994: 293),

a la que inmediatamente sucedió en otra misiva la puntual explicación del tema:

quatenus non solum magnitudo potestatis te regem ostendat, sed etiam instantia seminandi verbi Dei in laude nominis domini nostri lesu Christi predicatorem efficiat. Ideo divina te gratia his duobus mirabiliter ditavit muneribus, id est terrenae felicitatis imperio et spiritalis sapientiae latitudine, ut in utroque proficias, donec ad aeternae batitudinis pervenias felicitatem (DÜMMLER, 1994: 294).

Tras la coronación imperial del año 800, Alcuino compuso un largo poema, ad Carolum imperatorem-, donde se entrelazan todas las variantes posibles del tema davídico:

David amor populi, David laus, gloria plebis, atque decus regni, spesque corona suis (...)

Tu es pater patriae, praeclari et pastor ovilis (...)

O rex, o rector, o decus ecclesiae! (...)

Rectorem regni te Deus instituit.

grex est quippe tuus populus, tu pastor ovilis nobilis egregii, magnus in orbe pater (DÜMMLER, 1978b; 257-258).

En la misma fecha, Teodulfo de Orléans se sumaba al coro laudatorio, retomando los mismos motivos:
Nam tua prosperitas decus est et gloria plebis Christicolae, cui tu tutor es atque pater (...) Arma es pontificum, spes et defensio cleri, Per te pontifices iura sacrata tenent (...)

Tu regis ecclesiae, nam regit ille <papa> poli. Tu regis eius opes, clerum populumque gubernas (DÜMMLER, 1978b: 523-524)

Actividad ésta a la que se sumó otro de los miembros del círculo cortesano, Angilberto, en su Ecloga ad Carolum regem, en la que se insertan repetidas veces a lo largo del poema los versos:

David amat vates, vatorum est gloria David David amat Christum, Christus est gloria David (DÜMMLER, 1978b: 360-363).

El mismo autor, el año anterior a la coronación imperial, avanzaba el elogio davídico en los siguientes términos:

Spargit ad astra suum Carolus rex nomen opimum;

Sol nitet ecce suis radiis; sic denique david

Inlustrat magno pietatis numine terras (PERTZ, 1925a: 393).

Es preciso señalar, recogiendo la reflexión de Folz, que a partir del poema de Paulo Diácono, la aplicación del marchamo a Carlomagno se aleja de los antecedentes surgidos de la cancillería papal, para adquirir un tono independiente de toda mediación eclesiástica, en claro desafío a la sede bizantina, desde 787 ocupada por Irene (1989: 135-139). No obstante, y pese a la interpretación "cesaropapista" que este tratamiento y otros paralelos -como rex et sacerdos- y contemporáneos pudieran desencadenar, el entorno de Carlomagno permaneció siempre plenamente consciente de la barrera que la ordinatio clerical establecía, separando infranqueablemente al monarca-emperador del clero. Ello es especialmente patente en los Libri Carolini, redactados en la víspera del concilio de Frankfurt (794), donde el ataque a Bizancio se apoya en violentas diatribas contra el culto imperial sobreviviente en la nueva Roma y las pretensiones isoapostólicas del emperador (FICHTENAU, 1949: 63-65; FOLZ, 1989: 129-130). Del mismo modo, es 
preciso delimitar, con el mismo Fichtenau, el carácter ministerial del sacerdotium atribuido a Carlomagno: en calidad de vicario de Cristo, le corresponde la defensa de la Iglesia, de los contenidos de la fe y su difusión al pueblo. Nunca se atribuyó participación en la capacidad de acción sacramental, reservada al clero consagrado (1949: 66-68).

Ludovico Pío todavía participó en los primeros tiempos de su reinado de esta aclamación davídica. Así lo atestiguan las laudes compuestas en su honor por Amalario de Tréveris, en 820. A su lado, sin embargo, aparece la identificación con Salomón:

Divo Hludowico vita. Novo David perennitas. Da principi, Domine, vitam. Ipsi novo Salomoni felicitas. Pax mundi vos estis. Pio principi prosperitas. Domine, vitam ipsi concede. Vestra fides vos servet. Christus, quem vos honoratis, ipse vos servet. Potestatem vestram Deus conservet. Deus pacificet regnum vestrum. ludith orthodoxae, nobilissimae atque prudentissimae augustae salus per multos annos. Lumina pacis, Domine serva. Lumina mundi, Domine serva. Vita vestra tutela omnium est. Vestra fides ecclesiarum est gloria. Piissimos dominos nostros imperiales natos Hlotarium gloriosissimum coronatum et fratres eius Christus conservet. Ex proavis orthodoxos, Domine, serva. Custodes fidei, Domine, serva (DÜMMLER-HAMPE: 1995: 259; SCHRAMM, 1963: 239-240).

Sin embargo, el tono de alabanza no incorpora las connotaciones salvíicas que se atribuían a su padre. En el poema compuesto por Teodulfo de Orléans con ocasión de su subida al trono no figura referencia alguna al papel providencial de su reinado, limitándose a desearle triunfos militares y alegrías eternas (DÜMMLER, 1978b: 53I).

La comparación entre padre e hijo, en la generación de los nietos de Carlos, acentuó la diferencia entre ambos, adscribiendo al primero el carácter guerrero -David- y al segundo el de soberano amable -Salomón- (Carmen de exordio gentis francorum; BOSHOF, 1996: 3).

Esta identificación con Salomón compartieron igualmente sus hijos. Así, Carlos el Calvo, a tenor de lo que le escribió Ratramnus de Corbie en 850:

Cum virtus et sapientiam regiam maiestatem illustrent: virtus videlicet, qua adversarios expugnet, sapientia, qua reipublicae corpus omne disponat, magnificentiam vestram haec duo clarius attollunt, quod celestis sapientiae secreta perquiritis et religionis amore flagratis. Haec enim vos prioribus comparant principibus, qui virtutum potentia hostium colla subegerunt, et sapientiae fulgore et religionis honore amici Dei facti sunt: David dicimus et Salomonem, Ezequiam et Josiam, quibus sicut fuit studium circa divinae sapientiae mysteria detinere, ita eorum fama et inmortalis existit et stipendiis aeternae beatitudinis ornata refulget (DÜMMLER-PERELS, 1995: 149-150).

O Sedulio Scotto, para quien Salomón es motivo de múltiples relaciones:

Pacifer ut Salemon sceptra paterna tenes Ast uno Salemon templo celebratur in orbe: Mille sed hic templis eminet arte novis. Ille fuit Solimae rex inclitus atque celebris; Sed centum Solimas hic tenet altithronus. Illo gaudebant mons Sion, mons olearum; Hunc Alpes niveae respicunt niveum. Illum lordanes glaucis resonabat ab undis; Corniger hunc Rhenus personat huncque stupet. Mente Salemonis sapietia prisca refulsit; Hic nova cum priscis sacra fluenta bibit. Hunc mitis pietas, hunc ornat larga potestas, Diligit hunc Christus glorificatque deus, Gallicus orbis ovans tanto rectores coruscat, Itala quem sperat terra beata ducem.

Ad Salemona pium populus concurrit in unum; Caesaris es magni Ludewici stemma decoris, Isaac proles ceu benedicta micas: Habrahae similis Karolus perfulserat ingens, natus ut Isaac sic Ludewicus erat, Tertius es veluti lacob, benedictus et eres, Isaac patris Caesaris, alme, ducis. (TRAUBE, 1978: (80-|8|).

Versos repetidos en otro poema, variación sobre el precedente, en el que se preguntaba:

Dicite: cui populi conceditur ampla potestas lam prisci Karoli?: nonne novo Karolo? Ille fuit manibus fortis David velut alter Allophylos contra splendida castra movens: 
Hic sedet altithronus celsi Salemonis ad instar Floriferae pacis gaudia dans populis (TRAUBE, 1978: 193).

Lotario, en boca de Walahfrid Strabo:

In Christo valeas, optamus, magne Lothari

Bellipotens David, Salomon aut victor lohab (DÜMMLER, 1978a: 42I).

O del mismo Sedulio Scotto, en poema dirigido a su esposa Ermingarda:

Caesar amat talem Salemonemque Lotharius almam

Augustam niveam diligit ipse suam (TRAUBE, 1978: 187),

o al mismo Lotario:

Gnosce, Sion, dominum nunc Salemonem tuum (TRAUBE, 1978: 192);

David serena species, honora proles,

Alter Salemon redolens charisma pacis,

Sion venusta soboles, in orbe princeps (TRAU$B E$, 1978: 212-213).

Hic tuus est Salemon, felix o Francia, gaude: Pacificus princeps hic tuus <est> Salemon (TRAUBE, 1978: 216 ).

Rex tuus mitis, sapiens, honorus, pacifer ductor Salemonis instar

Nunc venit Caesar, tuus, alma, princeps,

Filia Sion (TRAUBE, 1978: 217).

Circunstancia que no le impidió dedicar otra alabanza en términos semejantes al tercero de los hermanos, Luis el Germánico:

Cunctus ab axe venit borealis climatis ordo,

Linguosus populus cunctus ab axe venit;

Te Salemona pium votis exoptat habere

Eligit in regem te Salemona pium (TRAUBE, 1978: 196).

A pesar de esta inequívoca asociación con Salomón de la descendencia de Ludovico Pío, aún resuenan ecos de la metáfora davídica en los poemas incorporados al códice de la Biblia que el monasterio de Viviano dedicó a Carlos el Calvo (850):

I. Vi David, intellectu salomon benedicto, in specie loseph, spe induperator ovans
VI. Exulta, laetare satis, rex inclite David. $X$. O decus, o veneranda salus, o splendide David Rex Carole alme, vige cunctipotentis ope. XI. Quos laudes tibi, quas grates, quae carmina, David,

Quod par dulce melos vox, lira, corda canet? (...) Sint tibi spes, virtus, lumen, victoria, Christus, Pax, laus continue: rex bone, David, ave (TRAU$B E$, 1978: 248-252).

Ecos que se perciben igualmente en la dedicatoria del Evangeliario de Munich (870):

Hic David vario fulgiscit stemmate regis Atque Salomonica iura docentis habet (TRAUBE, 1978: 252).

Por último, el epitafio de Otón I, atribuido a Odilón de Cluny, retoma la analogía davídica y salomónica, con clara concreción de las respectivas virtudes y sin que falte la asociación con Ezequías y Josías:

Hoc tegitur loco divus et maximus Otto, fortis in imperio, David ut tempore prisco, clarus ut ipse sophus Salomon et pacis amicus; Obstat Ezechiae maiori praeditus hic spe, ut pax eveniat, verum per saecula crescat. Phase sat celebre fecisse scribitur, ecce, atque suas ferias primus sub sole Josias (PERTZ, 1925b: 636).

Sin que se pueda excluir el influjo franco, en las actas del sínodo británico de 786, convocado por los legados del papa Hadriano ante Offa de Mercia y Cynewulf de Wessex, se recogen varios cánones relativos al comportamiento de y hacia el monarca, cuyo apoyo escriturístico consiste en citas de textos atribuidos a Salomón (Eccl, 5, 4; 10, 20; Sab, 20, 10) o referentes a David (I Reg, 24, 5; 26, I I; 2 Reg, I, I5; Ps, I4, I,5; 75, 12, I 3) (DÜMMLER, 1994: 24-26; STENTON, 1947: 215).

La elección de David como modelo de monarca cristiano implicaba asumir los rasgos que caracterizaron su ejercicio del poder: el rey es constituido pastor y guía de Israel -tu pasces populum meum Israel, et tu eris dux super Israel (2 Sam, 5, 2)-, establece su capital en Jerusalén (2 Sam, 5, 7), traslada a ella el Arca 
de Dios (2 Sam, 6), y propone la construcción de un templo donde se venere el nombre del Señor (2 Sam, 7, 4- I 7, 25-29). Se establece de este modo un programa de gobierno, que justifica por sí mismo su asimilación por todo gobernante cristiano, y explica la mención de David en la liturgia regia. Ahora bien, a tenor de los textos que venimos de colacionar, el factor que especifica la asimilación a David de los primeros carolingios es su doble componente de rey y profeta, caudillo a la vez laico y religioso. En el rito de la unción de Carlomagno a cargo del papa radicaba la legitimidad imperial de la dinastía, defendida frente a la resistencia de los emperadores bizantinos. Así lo expresa la célebre carta de Luis II, hijo de Lotario, a Basilio I en 87I, redactada por su protegido Anastasio Bibliotecario:

Nam Francorum principes primo reges, deinde vero imperatores dicti sunt, hii dumtaxat qui a Romano pontifice ad hoc oleo sancto perfusi sunt. In qua etiam Karolus Magnus, abavus noster, unctione huiusmodi per summum pontificem delibutus primus ex gente ac genealogia nostra pietate in eo habundante et imperator dictus et Christus Domini factus est, praesertim cum saepe tales ad imperium sint asciti, qui nulla divina operatione per pontificum ministerium proposita solum a senatu et populo nichil horum curantibus imperiatoria dignitate potiti sunt; nonnulli vero nec sic, set tantum a militibus sunt clamati, et in imperio stabiliti sunt, ita ut etiam horum quidam a feminis, quidam autem hoc atque alio modo ad imperii Romani sceptra promoti sunt.

Porro si calumpniaris Romanum pontificem, quod gesserit, calumpniari poteris et Samuel, quod spreto Saule, quem ipse iunxerat, David in regem ungere non renuerit (CASPAR-LAEHR, 1993: 389).

Las menciones a Salomón en la liturgia altomedieval son recurrentes en dos tipos de ceremonias: el rito de la coronación regia y la consagración de templos. Este última insiste en su recuerdo, pues la construcción del Templo de Jerusalén-Templo por excelencia- es el hecho más considerable de su reinado (I $\operatorname{Re}, 6-8 ; 2$ Par, 3-7). El rito hispánico in ordinatione regis prescribía la misma lectura del Libro de la Sabiduría -atribuido a Salomón, como es bien sabido- (IX I-12) que en el die Sabbato in sacratio- ne baselice quando sal adspargitur (PÉREZ DE URBEL y GONZÁLEZ RUIZ-ZORRILLA, 1950- 1955: II, 535-536).

Deus parentum meorum, et Domine misericordie qui fecisti omnia verbo tuo, et sapientia tua constituisti hominem, ut dominaretur creature subiecte que a te facta est, ut disponat orbem terrarum in equitate et iustitia, et in directione cordis iudicium iudicet: Da mici sedium tuarum adsistricem sapientiam, et noli me reprobare a pueris tuis, quoniam ego servus tuus, et filius ancille tue sum homo infirmus, et exigui temporis, et minor ad intellectum iudicii et legem. Tu me elegisti regem populo tuo, et iudicem filiorum tuorum et filiarum: et dixisti edificare templum in monte sancto tuo, et in civitate habitationis tue aram, similitudinem tabernaculi sancti tui quod preparasti ab initio; et tecum sapientia tua, quae novit opera tua, que et adfuit tunc cum orbem terrarum faceres, et sciebat quid placitum esset in oculis tuis, aut quid directum in preceptis tuis. Mitte illam de sanctis caelis tuis, emitte illam de sedem magnitudin<is> tue, ut mecum sit et mecum laboret, ut sciam quid acceptum sit aput te: scit enim illa omnia, et intellegit, et deducet me in operibus bonis sobrie et custodiet me in sua potentia. Et erunt accepta opera mea; et disponam populum tuum iuste, et ero dignum sedium patris mei.

La versión latina coincide salvo matices con la Vulgata, a excepción de la omisión en la perícopa hispánica del v. 6 (Nam et si quis erit consummatus inter filios hominum, si ab illo abfuerit sapientia tua, in nihilum computabitur). Se aúnan de este modo en la intención del liturgista la misma doctrina bíblica para la consagración del templo y para la ordenación del rey, puesta en boca del rey por excelencia, Salomón, promotor del primer templo.

En un panorama rápido sobre estas tradiciones litúrgicas podemos exhumar los siguientes paralelos, que prestan igual atención a la figura de Salomón en su doble carácter de modelo de rey y prototipo de constructor de templos.

I Pontificale Romano-germanicum, $X X X \mathrm{XV}$. (circa 950-963/964). Canon de aedificanda aecclesia. Una vez determinados el lugar y carácter de la dotación, el obispo levanta una cruz en el lugar donde se haya de colocar 
el altar, tras lo cual procede a la aspersión, acompañada del canto de la antífona Signum salutis pone Domine lesu Christe in loco illo et non permittas introire angelum percutientem, antífona que figura inequívocamente en inscripciones fundacionales de edificios altomedievales asturianos, como la fortaleza ovetense (875) o la fuente de Foncalada (GARCÍA DE CASTRO VALDÉS, 1995: 89, 92). A continuación, pronuncia el obispo la oración consecratoria del lugar:

Domine Deus, qui licet caelo et terra non capiaris, domum tamen tibi in terra fieri iussisti, in qua nomen tuum iugiter invocaretur, hunc locum, quaesumus, beatae Mariae semper virginis omniumque sanctorum tuorum intercedentibus meritis, sereno tuae pietatis intuitu visita et vide et illum ad fabricandum elige, perque infusionem gratiae celestis ab omni inquinamento purifica, purificatumque conserva, ut qui dilecti tui David devotionem in filii sui Salomonis opere complesti, tu famuli tui $N$. in hoc opere, ita precamur, vota perfice, ut illud te inspirante incipiat, te adiuvante perficiat, suique laboris praemium in terra consequatur viventium. Effugiant ergo hinc, iubente te, domine, omnes nequitiae spirituales et cum fraudibus suis cuncta diaboli turma, tua virtute depulsa. Resurgat hic aecclesiae tuae pura simplicitas et ammabilis tibi innocentiae candor, sicque hunc locum per unigeniti filii tui domini nostri lesu Christi dilectionem, coeterni tibi spiritus paraditi rore fecunda gratissimo, ut quicumque hic pro suis necessitatibus auribus tue benignitatis ingerit vota, votorum suorum consequatur effectum. (VOGEL-ELZE, 1963: 1, 122-123).

2 Pontificale Romano-germanicum, XL, Ordo ad benedicendam ecclesiam. 47: oratio in consecratione basilicae:

Deus sanctificationum, omnipotens dominator, cuius pietas sine fine sentitur, Deus qui celestia simul et terrena complecteris, servans misericordiam tuam populo tuo ambulanti ante conspectum gloriae tuae, exaudi preces servorum tuorum, ut sint oculi tui aperti super domum istam die ac nocte. Hanc quoque basilicam in honore sanctae et victoriosissimae crucis et sancti III. sacris mysteriis institutam clementissimus dedica, miseratus illustra, proprio splendore clarifica, omnemque hominem venientem adorare te in hoc loco placatus admitte, propitus respicere dignare et propter nomen tuum magnum et manum fortem et brachium excelsum, in hoc habitaculo supplicantes libens protege, dignanter exaudi, aeterna defensione conserva, ut semper felices semperque in tua religione letantes, constanter in sanctae trinitatis confessione fide catholica perseverent. (VOGEL-ELZE, 1963: I, 142).

3 Pontificale Romano-germanicum, XCIX, Ordo catholicorum librorum qui in ecclesia romana ponuntur, De letania minore, 423:

Exaudi, domine, deprecationem servorum tuorum et miserere populo tuo (...) Dimitte, domine, peccata populi tui secundum multitudinem misericordiae tuae (...) Exaudi, domine, populum tuum confitentem nomini tuo et dimitte peccata servorum tuorum et populi tui Israel (...) (VOGEL-ELZE, 1963: II, 121).

4 Ordo de coronación de Luis II el Tartamudo en Compiègne (877; recogido en el denominado Ordo C, circa 900). Oratio super regem, 4:

Omnipotens sempiterne Deus (...) qui Abraham famulum tuum de hostibus triumphare fecisti, Moysi et losue populo tuo prelatis multiplicem victoriam tribuisti, humilem quoque David puerum tuum regni fastigio sublimasti (...), et Salomonem sapientiae pacisque ineffabili munere ditasti, respice, quaesumus, ad preces humilitatis nostrae... (SCHRAMM, 1934: 203).

5 Ordo A, coronación de Luis II el Tartamudo por Juan VIII (Troyes, 7 de septiembre de 878). Benedictio supra regem, 4:

Visita eum sicut Moysen in rubo, losue in agro, lesu Nave un proelio, Samuhelem crinitum in templo, et illa eum promissione siderea ac sapientiae tuae rore perfunde, qua beatus David rex in psalterio, Salomon filius eius, te remunerante, percepit e caelo. (SCHRAMM, 1934: 194).

6 Ordo de coronación de Sankt Alban, Maguncia (recogido en el Pontificale romano-germanicum, circa 950-963/964, Ordo ad regem benedicendum quando novus a clero et populo sublimatur in regno). Benedictio, 9: 
Benedic, domine, hunc regem nostrum (...) Da ei tuo inspiramine cum mansuetudine ita regere populum, sicut Salomonem fecisti regnum obtinere pacificum...

\section{Benedictio, 10:}

Omnipotens sempiterne Deus (...) qui Abraham famulum tuum de hostibus triumphare fecisti, Moysi et losue populo tuo prelatis multiplicem victoriam tribuisti, humilem quoque David puerum tuum regni fastigio sublimasti (...), et Salomonem sapientiae pacisque ineffabili munere ditasti, respice, quaesumus, ad preces humilitatis nostrae (...) super hunc famulum tuum (...) benedictionum tuarum dona multiplica (...) quatinus predicti Abrahae fidelitate firmatus, Moysi mansuetudine fretus, losue fortitudine munitus, David humilitate exaltatus, Salomonis sapientia decoratus, tibi in omnibus complaceat... (SCHRAMM, 1935: 313314; VOGEL-ELZE, 1963: I, 250-25 I).

\section{Oratio, I1:}

Visita eum sicut Moysen in rubo, losue in agro, lesu Nave un proelio, Samuhelem crinitum in templo, et illa eum promissione siderea ac sapientiae tuae rore perfunde, qua beatus David rex in psalterio, Salomon filius eius, te remunerante, percepit e caelo. (SCHRAMM, 1935: 315; VOGEL-ELZE, 1963: I, 25 I-252).

7 Ordo F, coronación de Edgar de Inglaterra por Dunstan de Canterbury (Bath, II de mayo de 973). Consecratio regis, 6 :

Omnipotens, sempiterne Deus (...) super hunc famulum tuum (...) benedictionum tuarum dona multiplica (...) quatinus predicti Abrahae fidelitate firmatus, Moysi mansuetudine fretus, losue fortitudine munitus, David humilitate exaltatus, Salomonis sapientia decoratus, tibi in omnibus complaceat... (SCHRAMM, 1934: 224).

La razón de la insistencia en citar directa o indirectamente la figura de Salomón, al margen de las referencias explícitas a su papel como constructor del Templo por excelencia, podrían encontrarse en la segunda parte de la biografía del propio monarca. Tras los fastos de consagración, 3 Reyes, II , 4-8, narra la depravación del rey anciano, convertido al culto pagano por influjo de sus concubinas y esposas, lo que ocasionó la división del reino davídico a su muer- te, por designio de la Providencia. La figura gloriosa del monarca constructor perdió todo brillo y se hundió al abandonar el cumplimiento de la voluntad divina, cayendo en desgracia ante Dios. Un monarca pecador, alejado de Dios y justamente castigado por ello, resultó de este modo mucho más adecuado para la tarea de "liturgizar" y clericalizar el ejercicio del poder, siquiera fuese en el plano simbólico. Aún más, indicios tardíos de esta consideración de la persona de Salomón se contienen, por un lado, en el testamento -recogido en la Vita Bernwardi de Thangmar, 5l-del obispo Bernward de Hildesheim (+1022), el más grande de los prelados constructores coetáneos de la dinastía otoniana, quien buscó equipararse a Salomón por su condición de gran penitente:

Satis indicio est, quantus asurrexerit in praeliis David manu fortis, et sole lucidius est, structo tabernaculo Dei, quantis religionum ritibus et libaminum misticis cultibus se Deo approximaverit sanctus Salemon, cuius poenitentiae meritis nullus unquam repertus est similis. Quibus omnibus ad habitudinem factorum revelavit Deus secreta meritorum, ut temporaliter merito et opere omnibus semper essent dispares, insuper aeternaliter angelicis spiritibus fierent coaequales. Haec ego considerans Bernwardus, (...) et diuturna meditatione volvens, qua meritorum architectura, quove rerum precio possem mercari caelestia (...) quomodo aeternae satisfacere misericordiae sicque remedium meae obtinerem animae (PERTZ, 1925b: 779-780; SCHRAMM, 1963: 238; BINDING, 1996: 343).

Y, por otro, en la leyenda desarollada en torno a la última voluntad del obispo de Lieja Durandus (+1025), quien habría exigido ser enterrado en las afueras del templo de San Lorenzo, a fin de obtener por esta penitencia el perdón de su antecesor Wolbodo (+ 1021$)$, cuyo legado destinado a la construcción del templo había sido malversado por aquél (GIERLICH, 1990: 337-338).

Existen precedentes en la tradición exegética patrística sobre la figura de Salomón, que insisten en su condición de rey pecador, contraponiéndolo a su padre David, en quien se mantiene la promesa de salvación. Es especial- 
mente interesante en este contexto el Liber de XII abusionibus saeculi, del Pseudo-Cipriano, abundantemente citado por Jonás de Orléans e Hincmar de Reims:

Propter piaculum enim Salomonis regnum donus Israhel Dominus de manibus filiorum eius dispersit, et propter meritum David regis lucernam de semine eius semper in Iherusalem relinquit (REVIRON, 1930: I4I; DEVISSE, 1975-1976: 697).

De hecho, en Northumbria, la Vita Wilfridi eboracensis asimila la actividad constructiva del prelado a la de Salomón:

Wilfridus in Hripis basilicam polito lapide a fundamentis in terra usque ad summum aedificatam, variis columnis et porticibus suffultam, in altum erexit et consumavit (...) Consecrantes secundum sapientissimum Salomonem domum, Domino in honorem sancti Petri apostolorum principis dicatam (...) omnia kanonice compleverunt (KRUSCH-LEVISON, 1979b: 211).

En ello no se refleja sino una particular tendencia entre los promotores de edificios eclesiásticos, que remonta a la inscripción conmemoratoria de la iglesia de San Polieucto en Constantinopla (524-527) (BINDING, 1996: 340).

Paradójicamente, Salomón, a quien la tradición bíblica atribuía la composición de buena parte de los libros sapienciales -Proverbios, Ecclesiastés y Cantar de los Cantares-, no parece haber gozado del carácter profético. Es sinónimo de prudencia, sabiduría e interés por los asuntos divinos, mas no goza del papel de heraldo de Dios, del que se vio revestido su padre. La exégesis altomedieval sobre la figura de este monarca está dominada por dos textos provenientes de las plumas de Agustín de Hipona e Isidoro de Sevilla. El primero, en De Civitate Dei (XVII, 8, 20; PL. XLI, 54I, 554), estableció el primer juicio histórico sobre su persona, en estos términos:

Facta est quidem nunnulla imago rei futurae etiam in Salomone, in eo quod templum edificavit et pacem habuit secundum nomen suum (Salomon quippe pacificus est latine) et in exordio regni sui laudabilis fuit ... Hic bonis initiis, malos exitos habuit.
El contexto de ambas citas es la demostración de que la promesa de redención efectuada a David no se cumplió históricamente en su descendencia física -su hijo y sucesor Salomónsino en Cristo, nacido de la estirpe davídica.

Por su parte, Isidoro de Sevilla recogió este juicio agustiniano, transmitiéndolo a la posterior tradición exegética sobre los Libros de los Reyes, añadiendo una valoración propia, incorporada sin variación por los exegetas posteriores (Quaestiones in veterum Testamentum, In libros Regum, PL, LXXXIII, 4|4, 4|7-4|8):

Apparet enim in persona eius Salomonis mira excellentia et mira subversio. Quod igitur in illo diversis temporibus exstitit prius bonum et posterius malum, hoc in Ecclesia in isto adhuc saeculo, simul et uno tempore ostenditur. Nam bono illius bonos Ecclesiae, malo autem illius, malos Ecclesiae significatos puto, tamquam in unitate illius areae sicut in illo uno homine bonos in granis, malos in paleis, aut in unitate unius segetis, bonos in tritico, malos in zizaniis.

Beda (Quaestiones in libros Regum, PL, XCIII, 444-447), Claudio de Turín (Quaestiones super libros Regum, PL, CIV, 722, 739-740), Raban Maur (Commentarii in libros Regum, PL CIX, 199; Commentarii in Paralipomena, PL, CIX, 482) y Angelomus de Luxeuil (Enarrationes in libros Regum, PL CXV, 470), reproducen ambas citas, con lo que quedaba establecida firmemente la sentencia sobre Salomón en términos teológico-históricos. Es de destacar que ninguno de estos comentaristas presta la menor atención a la Oratio Salomonis. No obstante, Amalario recoge en el Liber de ordine Antiphonarii ( $L X X I 1$ : De respnsoriis qui praetitulantur de Salomone sive de Sapientia) una interpretación diferente de Salomón. No estaría exento de la virtud de la fortaleza, genuina de su padre, pues la sabiduría es sinónima de la fortaleza:

David strenuus in bellicis rebus, Salomon strenuus prae ceteris in sapientia; nam et sapiens vir fortis dicitur. Unde Horatius poeta:

Fois et in seipso totus, teres atque rotundus.

Merito qui sapientia pollet, fortis dicitur. De qua scriptum est: sapientiam vincit malitiam (HANSSENS, 1948-50: 111, 101). 
Se explica así que la teología política elaborada en torno a Pipino y Carlomagno insista en la asimilación a David, rey elegido por Dios para dotar a su pueblo de rector y guía estable. La debilidad del papado coetáneo permitió la asunción por parte de ambos monarcas francos, sobre todo por parte del segundo, del papel de directos intermediarios entre Dios y el populus christianorum, al modo del ancestro bíblico. Sus sucesores, sin embargo, no gozaron del mismo poder. Los eclesiásticos contemporáneos redujeron la teología política precedente a términos más acordes con la teoría cristiana del poder, tal y como había sido desarrollada por los papas del siglo V León I y Gelasio. Tras el fracaso de Luis el Piadoso en 833 no fue posible identificar al soberano con el autosuficiente David. Restaba Salomón, encarnación de la sabiduría atenta en todo momento a escuchar la voz de Dios, y ejemplo acabado de humanidad donde se entremezclan inextricablemente gracia y pecado, en anticipación de la Iglesia militante. Y posteriormente, los reyes bíblicos Ezequías y Josías, volcados en la restauración de la vida religiosa de Israel.

\section{LA DONACION REGIA DE TEMPLOS EN EL REINO DE ASTURIAS Y EL TESTAMENTUM DE ALFONSO II}

La tradición de donaciones regias a templos o basilicas en la Hispania paleocristiana y altomedieval anterior a la fecha de Naranco (848) consta fundamentalmente de textos redactados en primera persona, en los que el donante, aun adoptando tono penitencial, expresa ostensiblemente su voluntad, manifiesta en el diálogo directo que establece entre el donatario -sobrenatural, Dios, la Virgen María, santos o mártires- y su propia persona. Ejemplo destacado se encuentra en la inscripción de dedicación de la basilica de San Juan de Baños (66I; Palencia), ofrecida por Recesvinto, devotus ego rex amator nominis tui (NAVASCUÉS, 1961: 8). No obstante, la misma disposición se aprecia en inscripciones conmemorativas de actos llevados a cabo por personajes no regios, como el anónimo donante de la cruz de Torredonjimeno (VIVES, 1944):

\section{PECCAVI DOMINE ET PECCATUM MEUM AGNOSCO \\ PIETATE CONSUETA DIMITTAS ADCLINUS \\ OMNIA \\ DELICTA IUBENTUTIS ET IGNORANTIAE}

o el obispo Ermefredo de Lugo, restaurador del monasterio de Samos (Lugo) en los años 653-656 (MUNDÓ, 1961: 157-164).

En el Reino de Asturias el primer testimonio de dedicación de un templo es el de la Santa Cruz de Cangas de Onís, consagrado en el año 737 por voluntad de Fáfila y su esposa Froiliuva (GARCÍA DE CASTRO, 1995: I8 I - 84; DIEGO SANTOS, 1994: 226-227; ARBEITER Y NOACK-HALEY, 1999: 96-99). Los oferentes aparecen mencionados en tercera persona, calificados como famuli, dentro de una oración invocatoria en la que se ruega a Cristo que les alcance con su gracia y misericordia. Falta toda alusión penitencial y expiatoria de los donantes.

Tras él, no se nos han transmitido textos completos de dedicación u ofrenda de templos hasta tiempos de Alfonso II (79|-842). Referidos a este personaje disponemos de varios textos, cuyo análisis resulta pertinente en la comparación con la inscripción de Naranco. En primer lugar, una fragmentaria inscripción procedente de San Tirso de Oviedo, templo cuya fundación, en las crónicas redactadas bajo Alfonso III, es atribuido al propio Alfonso II (GIL et al, 1985: |38-141, 174). Desarrollada en diez líneas actualmente legibles-, contiene elementos penitenciales, combinando primera y tercera persona, sin aludir al cargo del donante. El tenor del texto conocido con seguridad, a partir de los restos hoy visibles y testimonios fidedignos de Ciriaco Miguel Vigil, es el siguiente (GARCÍA DE CASTRO, 1995: 155-157, 184)

QVISQVIS HIC IN HANC
BASILICAM PRO SVA DELICTA
DEVM DEPRAECAVERIT
CHRISTVS EVM EXAVDIAT
ADEFONSVM IN MENTE HABEAT
DIMISSA SINT MICI PECCATA
IN AETERNVM

IN AETERNVM 
Al círculo del mismo monarca se atribuyen las dos perdidas inscripciones de renovación y dotación de la basilica del Salvador, en Oviedo, cuyo texto nos ha sido transmitido en el Liber Testamentorum de la misma iglesia (VALDÉS GALLEGO, 2000: 457-458; GARCÍA DE CASTRO, 1995: 177-179). En la segunda de ellas, Alfonso establece una fundación perpetua de misa semanal por su alma, a la vez que, en la segunda parte del texto alude al acto de ofrenda en estos términos:

TUA SUNT, DOMINE, TUA OMNIA QUAE TU INSPIRASTI VEL CONFERRE NOBIS DIGNATUS ES. TIBI, DOMINE, TUA OFFERIMUS. HUIUS PERFECTAM FABRICAM TEMPLI EXIGUUS SERVUS TUUS ADEFONSUS EXIGUUM TIBI DEDICO MUNERIS VOTUM. ET QUOD DE MANU TUA ACCEPIMUS, IN TEMPLO TUO DANTES, TIBI GRATANTER OFFERIMUS.

La fórmula inicial de este texto encuentra un significativo paralelo en el denominado testamentum regis Adefonsi, documento fechado el 16 de noviembre de 812 y conservado en un cuadernillo fechado por razones paleográficas y codicológicas en los últimos años del siglo IX O primeros del X (GARCíA LARRAGUETA, 1962: 7; RODRÍGUEZ DÍAZ, 1995-97: 78). Probablemente por influjo de la cancillería ovetense, la fórmula pasó a ser incluida en varios documentos de donación regios en el siglo $X$ (donación de diversos ornamentos y bienes a San Salvador de Oviedo por Alfonso III y Jimena, 908; donación del valle de Sariego a San Pelayo de Oviedo por Vermudo II, 996; donación del monasterio de Borvene a Santiago de Compostela por Ordoño III, 95I) (GARCÍA LARRAGUETA, 1962: 74; FERNÁNDEZ CONDE, TORRENTE Y DE LA NOVAL, 1978: 20; LUCAS ÁLVAREZ, 1998: 103), apareciendo en documentos particulares laicos y clericales en el XI (GARCÍA DE CASTRO, 1995: 179), siendo utilizada igualmente por notarios episcopales, como el de Ranulfo de Astorga (donación del lugar de Redelga a San Pedro de Montes, 892; QUINTANA PRIETO, 1968: 58-59), San
Genadio de Astorga (donación del monasterio de San Alejandro, 9I5; QUINTANA PRIETO, 1968: 203), San Fortis de Astorga (donación al monasterio de San Dictino de Astorga, 925; QUINTANA PRIETO, 1968: 274), o jimeno de la misma sede (sendas donaciones al mismo manasterio astorgano de San Dictino, 1014 y I020; IBIDEM, 547$548,552)$, sin que falten ejemplos gallegos, procedentes del monasterio de Celanova (donación de Froila, hermano de San Rosendo, y su esposa Sarracina, 936; SÁEZ Y SÁEZ, 1996: 125) o astorganos (donación del presbítero Bonel a la sede astoricense, 1036, donación de Haceme Ensilaz a la misma sede, I058; QUINTANA PRIETO, 1977: 575, 587-588). Su tenor es el siguiente:

Tua sunt Domine omnia et que de manu tua accepimus tibi conferimus.

Como en el caso del texto de Naranco, esta fórmula responde a cita bíblica: I Par, 29, |4-16:

Tua sunt omnia: et quae de manu tua accepimus dedimus tibi (...) Domine Deus noster, omnia haec copia, quam paravimus ut aedificaretur domus nomini sancto tuo, de manu tua est, et tua sunt omnia.

El contexto de la cita es claro: la acción de gracias de David en vísperas de su muerte, ofreciendo los recursos para la obra del templo de Jerusalén, cuya ejecución encomienda a su hijo Salomón. Se conocen empleos paralelos de esta "fórmula de devolución" a Dios de los bienes recibidos en diversas inscripciones pavimentales de templos italianos paleocristianos, que incluyen las palabras de donis en el tenor de la inscripción de donación de la obra del pavimento musivo, así como sobre objetos móviles, habiéndose rastreado su eco en las fórmulas del Canon eucarístico de los Sacramentarios Gelasiano y Veronense (CAILLET, 1993: 4I0-4II).

Este documento presenta una notable invocación, cuya literalidad responde a cita textual de oraciones litúrgicas hispánicas 7 : fons vitae, 0

7 Buena parte de los investigadores y estudiosos de este texto atribuyen esta invocación y los párrafos más líricos del mismo a factores biográficos, interpretándolo como reflejo del alma del propio monarca o como cuidada elaboración del escriba, fiel intérprete del sentir de Alfonso II (FLORIANO CUMBREÑO, I949-1950: I, I I 8-I42; SÁNCHEZ ALBORNOZ, I972-1975:II, 567-575). La 
lux auctor luminis, alfa et omega, initium et finis, radix et genus David, stella splendida et matutina. Su contexto más frecuente son las celebraciones de la Vigilia Pascual y la Epifanía del Señor, tal y como queda de manifiesto en los siguientes paralelos.

- Oracional Veronense, 40I: orationes in die Apparitionis Domini.

Alfa et Omega, principium et finis, radix, genus, filius, dominusque david, Christus, Deus et homo (VIVES Y CLAVERAS, 1946: 135).

- Oracional Veronense, 839: In die sancti Torquati, alia.

Deus Dei filius, lumen astrorum, fulgor siderum, stella splendida et matutina, claritas sempiterna et sanctorum eruditio copiosa (VIVES Y CLAVERAS, 1946: 314).

- Antifonario Legionense, fol. 85, 87: officium in diem Apparitionis Domini, ad Matutinum.

Ego sum alfa et omega primus et nobilissimus principium et finis ego sum radix et genus David, stella splendida et matutina (BROU Y VIVES, 1959: 116, 119, 120).

- Liber Misticus de Cuaresma, n² 243: Sabbato I hebdomada.

Deus, creator omnium/ lucis auctor et diei (JANINI CUESTA, 1979: 45).

- Liber Misticus de Cuaresma, $n^{\circ}$ I355: Post Ramos palmarum, II Feria ad vespera. Completuria.

Deus, auctor luminis, conditor claritatis (IANINI CUESTA, 1979: 219).

- Liber Misticus de Cuaresma y Pascua, n 80: II Dominica. Imnus.

Auctor luminis, filius insignis/ Paterque matris filiusque patris (JANINI CUESTA, 1980: 12).
- Liber Misticus de Cuaresma y Pascua, nº 66l: Sabbato in vigilia Pasche, ad sanctificandum lumen oratio.

Exaudi nos, lumen indeficiens, domine deus noster, unici luminis lumen, fons lumen, lumen auctor luminum qui creasti atque inluminasti (JANINI CUESTA, 1980: 95).

- Liber Ordinum Episcopalis, n 424: Benedictio lucerne in sacrario.

Exaudi nos, lumen indeficiens, domine deus noster, unici luminis lumen, fons lumen, lumen auctor luminum qui creasti atque inluminasti (JANINI CUESTA, 1991: (87).

- Liber Ordinum Episcopalis, n 269: Oratio ad commendandum corpus Deo votae virginis.

Sicque te auctorem lucis fontemque reperiens perpetui luminis (JANINI CUESTA, 1991: 144).

- Liber Missarum de Toledo, no 184: Missa de initio anni.

Christe, qui es alpha et omega, initium et finis (JANINI CUESTA, 1982: 1, 63).

- Hymnodia gothica, n I3: Feria III post octava Epiphanie, In laudibus.

Deus Aeterni luminis/ candor inenarrabilis/ venturus diei iudex/ qui mentis occulta vides.

- Hymnodia gothica, $n^{\circ}$ 17: Dominica II post Epiphaniam, ad vesperas.

O lux beata Trinitas/ et principalis unitas/ iam sol recedit igneus/ infunde lumen cordibus.

- Hymnodia gothica, $n^{\circ}$ 18: Dominica II post Epiphaniam, ad vesperas.

Christe, lux mundi, salus et potestas.

- Hymnodia gothica, n²0: Infra hebdomadam I Quadragesime, feria III ad vesperas.

Christe lumen perpetuum/ astrorum, fulgor sidereum.

\footnotetext{
prueba textual que aportamos permite aclarar este extremo, a la vez que lo sitúa en un tipo diplomático aún por definir con mayo nitidez. Más aún, la invocación continúa calificando a Cristo como rex regum regens celestia simulque terrestria, en lo que puede interpretarse como eco de los apelativos con que el celebrante se dirige a Dios en las missae votivae de rege (Liber ordinum, ed. JANINI CUESTA, 199|: 234-237): $n^{\circ}$ 665: qui es rex regum et dominus dominantium; $n^{\circ}$ 669: vere sanctus vere benedictus dominus noster lesus Christus deus deorum et dominus dominantium, princeps principum et imperator regum terrae; $\mathrm{n}^{\circ} 67 \mathrm{I}$ : Deus pater omnipotens qui es rex regum et dominus omnium potestatum.
} 
- Hymnodia gothica, n²2: Infra hebdomadam I Quadragesime, feria VI in laudibus.

Aeternae lucis conditorl lux ipse totus et dies/ noctem nec ullam sentiens/ natura lucis perpeti.

- Hymnodia gothica, n 24: Infra hebdomadam I Quadragesime, sabbato in laudibus.

Deus creator omnium/ lucis auctor et diei.

- Hymnodia gothica, n² 25: Dominica II Quadragesime ad vesperas.

Auctor luminis, filius virginis.

- Hymnodia gothica, $n^{\circ}$ 35: In Resurrectione Domini, ad primam.

Te lucis auctorl huius catervae carminal quam tu replesti gratial Anastasis potentia.

- Hymnodia gothica, n 75: Ad completorium diebus dominicis.

Christe, qui lux es et dies/ noctes tenebras detege/ lux ipse lucem praeferens/ lumen beatum praedicans.

- Hymnodia gothica, n 76: Ad completorium, in Quadragesima.

Lucis auctor clemens, lumen immensum/ lumen cuius fulget sanctus aeternus/ Christus, cum quo regnat, cum ipso in unum/ et sanctus spiritus, una potestas.

- Hymnodia gothica, n | 19: In SS. Facundi et Primitivi.

Fons, Deus aeternae pacis/ lux, origo luminis.

- Hymnodia gothica, $n^{\circ}$ I23: In Sancti Felicis.

Fons, Deus, vitae perennis/lux, origo luminis. (BLUME, 1897: 70, 72, 73, 76, 77, 78, 79, 87, III, 112, 17I, 177; KRINKE, 1954: 78; GARCÍA DE CASTRO VALDÉS, 1995: 368).
Concebido como una invocación del propio Alfonso en primera persona a Cristo, al que sigue una exposición histórico-biográfica, tras la cual se enumera el contenido de la donación, el testamento presenta un sorprendente paralelo con el documento por el cual San Rosendo dota el monasterio de San Salvador de Celanova (Orense) el 26 de septiembre de 942 (SÁEZ Y SÁEZ, 1996: |51-158). Abunda este texto en citas bíblicas y en reminiscencias de fórmulas litúrgicas, que superan notablemente en extensión el documento ovetense. No obstante, la diferencia esencial entre ambos radica en que en el texto ovetense habla un gobernante laico, mientras que en el de Celanova se expresa un obispo-monje. Los rasgos penitenciales adoptan una expresión mucho más acentuada en el segundo -cum peccatorum mole depressus in sola Mediatoris pietate respirans (...) undique caligo iniquitatis turbatus- que en el primero, donde se difuminan en menciones generales a los pecados colectivos, de Fruela I, padre de Alfonso, de éste y del pueblo a éste encomendado:

Omnia vero que ibidem per testamentum $<$ Froila $>$ contulit, conscripsit, firmabit ad veniam illius nobisque profuturam, ob honorem tuum firmum perenni iure decernimus super adicientes, et nos, Domine, laudi tue cum laude laudis vota offerimus, et cum toto munera dedicamus, poscentes ut, tam nos quam plebem nobis a te commissam, virtutis tue dextera protegas, et victrici manu contra adversarios fidei vistores efficias, clementie tue dono ita iustifices, ut cuncti qui hic operantes ad recuperacionem domus tue obedientes exstiterunt, suorum omnium abolitione excipiant peccatorum, quatenus et hic exclusa fame, peste, morbo,et gladio, defensi clipeo protectionis tue, felices se esse gaudeant et futuro in seculo feliciores cum angelis celestia regna possidean ${ }^{8}$.

8 Una intitulación semejante, plena de contenido teológico y con ecos de prosa litúrgica figura en dos donaciones de Ordoño II de León y su esposa Elvira de sendos terrenos para construir cenobios en el Valle Cesarii $(916$, enero, 9) y en Pardomino (917, enero, 8) (SÁEZ, 1985: 56-58, 64-68). La diferencia esencial con el documento ovetense de 812 está en la ausencia de destinatario físico en Oviedo, mientras que se encuentra plenamente presente en León -los respectivos abad Servando y confesores Trasmundo y Recesvindo-. Recientemente hemos propuesto como posible explicación de este hecho la inexistencia de obispo en Oviedo en la fecha indicada (GARCÍA DE CASTRO, 1999b: 42), lo que no excluye otra razón, como la apuntada comunicación sin intermediario entre el monarca y el donatario sobrenatural. La invocación de estos mismos documentos contiene asimismo significativas menciones a la unción regia como fuente de legitimidad: Fons magnae virtus...qui et reges unguere utiliter fecit 
El mismo testamentum regis Adefonsi, redactado en forma de plegaria personal puesta en boca del propio donante, equipara la acción de éste con la de otro personaje bíblico, Jacob, de este modo:

Tu fortissime Domine qui es Deus absconditus Deus Srahel Salvator qui iussisti lacob reuertere in terram natiuitatis sue altari constructo tibi munera offerre. Et nos pie dignatus de multis tribulationibus eruendo in proprio patrio domo reducere sit munus hoc tibi acceptum sicut accepta habuisti munera predicti lacob pueri tui...

La alusión a otro momento crucial de la historia de la salvación es patente. Dios ordena a Jacob el regreso a su tierra tras haber ido en busca de esposa a la tierra de Labán (Gén, $31,13)$, y le indica la erección de un altar en Bethel (Gén, 35, 1-7), tras haber luchado con el ángel (Gén, 32, 24-32). Jacob había invocado previamente a Dios en Socoth, donde había levantado un altar (Gén, 33, 17-20). Tras el sacrificio en Bethel, -surgite et ascendamus in Bethel, ut faciamus ibi altare Deo: qui exaudivit me in die tribulationis meae et socius fuit itineris meiDios renueva en Jacob y su descendencia la promesa y alianza establecida con Abraham, cambiando el nombre de Jacob por el de Israel (35, 9-15). De estos pasajes proceden los calificativos con que se caracteriza a Dios en el citado documento: Jacob invocavit super illud fortissimum Deum Israel (33, 20). Jacob lucha con el ángel, a quien pregunta por su nombre, sin alcanzar a conocerlo. Es ésta, a mi juicio, la razón del empleo en el testamentum del adjetivo absconditus, que respondería más al carácter incognoscible de Dios, sobre el cual todo conocimiento proviene de la revelación, que a su invisibilidad física. ${ }^{9}$ No creo que se violente la intención del redactor de este texto ove- tense si se supone que la razón de incluir esta referencia no es sino fundamentar bíblicamente el carácter fundacional del reinado de Alfonso II, pastor de una nueva grey a él encomendada por Dios. Esta interpretación se refuerza si atendemos al contenido de la narración histórica incorporada tras la invocación:

Sed quia te offendit eorum <id est: gotorum> prepotens iactantia in era DCCXLVIIII ${ }^{a}$ simul cum rege Roderico regni amisit gloria, merito etenim arabicum sustinuit gladium, ex qua peste tua dextera, Christe, famulum tuum eruisti Pelagium, qui in principis sublimatus potentia, victorialiter dimicans hostes perculit et christianorum asturumque gentem victor sublimando defendit, cuius ex filia filius, clarior regni apice, Froila extitit decoratus.

Con toda claridad se expresa en este párrafo una interpretación de la historia hispánica a partir del apogeo del reino de los godos, en términos de ruptura. La prepotencia de los godos ofendió la Divina Providencia, quien se sirvió de la espada musulmana para hacer justicia, a partir de lo cual suscitó la figura de Pelayo, siervo de Cristo, vencedor de los musulmanes y defensor de astures y cristianos, cuyo nieto Froila -hijo de su hija- brilló en el centro de poder ${ }^{10}$.

En relación con esta concepción fundacional del reinado de Alfonso II, es procedente examinar el paralelo que ofrecen al respecto las actas repetidamente citadas del III Concilio Toledano. En las laudes finales se glorifica a Jesucristo por haber suscitado una sola grey y un solo pastor, uniendo el tan ilustre pueblo de los godos a la verdadera fe -qui tam inlustrem gentem unitati verae fidei copulavit, et unum gregem et unum pastorem instituit-. Tal y como ha pues-

\footnotetext{
9 En este sentido, estimo, ha de interpretarse la aparición de este adjetivo, sin que haya pie para deducir de su presencia una teoría iconológica en favor del aniconismo programático del Alfonso II, que encontraría expresión perfecta en el contenido de las pinturas murales del interior del templo de Santullano, en Oviedo, como propuso en su momento Bango Torviso (I988: 235). Es precio reseñar, que de forma totalmnte independiente y dentro de un contexto diferente, la asociación de Alfonso II con Jacob se encuentra recogida en el volumen denominado "Jacob en Bethel" de la serie de historietas dibujadas "la crónica de Leodegundio", de la que es autor Gaspar Meana, editada por Llibros del Pexe en Gijón.

I OEn este trabajo no se puede avanzar más en el análisis de este problema, que sólo en los últimos tiempos ha vuelto a ser considerado por los investigadores: el origen y fundamento de la legitimidad política en el reino de Asturias. Es patente que el intelectual responsable de este texto se hallaba en las antípodas de cualquier ideal neogótico, sea cual sea la fecha de su composición.
} 
to de manifiesto Claude, las laudes confieren a Recaredo el officium apostolicum, en lo que no deja de traslucirse la referencia explícita a la condición de isoapóstolos del emperador bizantino, que bien pudo llegar al Concilio por la mediación directa de Leandro y Juan de Bíclaro, ambos exiliados largos años en Constantinopla. Este mismo cronista sitúa el papel de Recaredo en el III Concilio de Toledo en la misma posición que los de Constantino respecto al de Nicea y Marciano respecto a Calcedonia (CAMPOS, 1960: 98; Chron., anno VIII Mavricii imperatoris; CLAUDE, 1971: 77-80; STROHEKER, 1965: 233) '". Precisamente, la advocación de la basílica principal del conjunto catedral ovetense es el Salvador y el colegio apostólico, en patente recuerdo a las sedes catedralicias de Roma y Constantinopla (GARCÍA DE CASTRO VALDÉS, 1999b: 61). Quizás se pueda interpretar el hecho -entre otros factores- como testimonio de la concepción isoapostólica del entorno intelectual de Alfonso II, heredera de la de Recaredo. Apoyaría esta tesis el hecho significativo de que el mismo Alfonso II se intitule servus Christi en la inscripción de donación de la Cruz de los Ángeles a San Salvador de Oviedo en 808. Lejos de referirse a una imaginaria -e imposible- condición monástica del rey, como ya hemos señalado (GARCÍA DE CASTRO, 1995: 463464), la fórmula refleja la aspiración a la condición isoapostólica de la autoridad laica que la emplea, tal y como sucedió casi dos siglos después con Otón III, cuya cancillería la utilizó sistemáticamente en cuantos documentos fueron expedidos a lo largo del viaje misionero del emperador desde Roma a Polonia en 9991000, como prueba práctica de que la tarea de acrecentamiento de la Cristiandad que acometía el emperador en el viaje le confería temporalmente el carácter apostólico (SCHRAMM, 1984: 142-146; ALTHOFF, 1996: 136-137). Parece apreciarse una evolución en su uso desde tiempos paleocristanos, pues esta fórmula devocional de humildad aparece empleada por obispos o simples diáconos, según atestiguan las inscripciones pavimentales ( $n^{\circ} 6,1$ I y 42) de la catedral de Santa Eufemia de Grado (CAILLET, 1993: 225, 231-232, 248-249), o la inscripción del ambón ofrecido por el obispo Agnellus a la catedral ortodoxa de Rávena (CAILLET, 1993:

\footnotetext{
I I No deja de resultar extraño, por ello, que se haya intentado proponer una directa inspiración en la figura de Leovigildo para el reinado de Alfonso II (BANGO TORVISO, 1992: 27-29). La tradición historiográfica hispánica, desde Juan de Bíclaro a las crónicas asturianas, no ofrecen ningún apoyo para este tesis, más bien al contrario. Leovigildo llevó sobre sí la mancha de su confesión arriana. El Biclarense, puntual narrador de las actividades del monarca, no expresó juicio favorable alguno hacia su persona ni su reinado, frente a las alabanzas que tributó a Recaredo (CAMPOS, 1960: 98). Isidoro de Sevilla contrapuso las figuras de padre e hijo, con clara ventaja en favor del segundo, tras haber descalificado la obra del primero por el error de la impiedad: Reccaredus regno est coronatus, cultu praeditus religionis et moribus paternis longe dissimilis: namque ille irreligiosus et bello promptissimus, hic fide pius et pace praeclarus, ille armorum artibus gentis imperium dilatans, hic gloriosus eandem gentem fidei tropheo sublimans. In ipsius regni sui exordiis catholicam fidem adeptus totius Gothicae gentis populos inoliti erroris labe detersa ad cultum rectae fidei revocat (RODRÍGUEZ ALONSO, 1975: 260; Hist., 52), finalizando su exposición del reinado con un elogio hagiográfico: 55. (...) fuit autem placidus, mitis, egregiae bonitatis tantamque in vultu gratiam habuit et tantam in animo benignitatem gessit, ut in omnium mentibus influens etiam malos ad affectum amoris sui adtraheret; adeo liberalis, ut opes privatorum et ecclesiarum praedia, quae paterna labes fisco adsociaverat, iuri proprio restauraret; adeo clemens, ut populi tributa saepe indulgentiae largitione laxaret. 56. Multos etiam ditavit rebus, plurimos sublimavit honoribus, opes suas in miseris, thesauros suos in egenis recondens, sciens ad hoc illi fuisse conlatum regnum, ut eo salubriter frueretur, bonis initiis bonum finem adeptus; fidem enim rectae gloriae, quam initio regni percepit, novissime publica confessione paenitentiae cumulavit. Toleto fine pacifico transiit (RODRÍGUEZ ALONSO, 1975: 266). Isidoro continuó elogiando a otros monarcas visigodos, sobre todo a Suíntila (IBÍDEM: 278). La tradición cronística ovetense, representada por el denominado Albeldense, no se apartó de la consideración negativa que merecía Leovigildo: Suis perniciosus fuit: potentes per cupiditatem damnavit (XV, 19; GIL ET AL, I985: 169), mientras que Recaredo tempora sui regni omni bonitati ornabit (XV, 20; IBIDEM). Es más, al mismo Alfonso II se le aplican por el redactor de la versio ad Sebastianum de la Crónica de Alfonso III los mismos epítetos que las laudes regiae del III Toledano a Recaredo: Ipse sit Deo et hominibus amabilis, qui tam mirabiliter Deum glorificavit in terris (MARTíNEZ DÍEZ Y RODRÍGUEZ, I992: 74). Regni gubernacula gerens amabilis Deo et hominibus (Crón. Adef. III, 22; GIL ET AL, 1985: I4I). Incluso se podrían escuchar ecos del Decretum final del IV Concilio Toledano en las líneas que narran en las crónicas asturianas la muerte de Alfonso II. Compárese el texto visigótico: Corroboret Christi gloria regnum illius gentisque gotorum in fide catolica; annis et meritis protegat illum usque ad ultimam senectutem summi Dei gratia, et post praesentis regni gloriam ad aeternum regnum transeat ut sine fine regnet qui iuxta saeculum feliciter imperat (MARTÍNEZ DÍEZ Y RODRÍGUEZ, 1992: 259), con los textos asturianos: Chron. Adef. III, versio ad Sebastianum, 22: Qui prefatus Adefonsus rex per multis spatiis temporum gloriosam, castam, pudicam, sobriam atque inmaculatam vitam duxit, atque in senectute bona post LII annis regni sui sanctissimum spiritum permisit ad celum (GIL ET AL, 1985: 142); Chron. Alb., 9: Absque uxore castissimam vitam duxit. Sicque de regno terre ad regnum transiit celi (GIL ET AL, 1985: 175). Por nuestra parte, ya señalamos el carácter formulario de la caracterización de la vida de Alfonso II en este párrafo, con paralelos en la epigrafía paleocristiana y en la liturgia hispánica, en especial el ordo penitentie y la missa pro rege dicenda, del Liber ordinum (GARCÍA DE CASTRO VALDÉS, I995: 464). Por todo ello, la tesis de Bango Torviso parece más bien proceder de un apriorismo interpretativo más que de un análisis reposado de las fuentes históricas.
} 
4l I), lo que indica que no había asumido aún la connotación de máxima autoridad que revela su uso en los siglos IX y $X$.

No obstante lo apuntado anteriormente, el empleo de esta fórmula devocional se documenta en estos tiempos altomedievales en documentos compostelanos de Alfonso III (donación de 6 de mayo de 899, con ocasión de la consagración del templo; LUCAS ÁLVAREZ, 1998: 74) y de Ordoño II (confirmación de donaciones anteriores de 22 de abril de 9| I; |B|DEM: 80), y en una donación de Ordoño III al monasterio de Sahagún, del 15 de mayo de 951 (MÍNGUEZ FERNÁNDEZ, 1976: 170), así como por miembros del clero, como atestiguan documentos del obispo Genadio de Astorga, del año 920 (QUINTANA PRIETO, 1968: 21 I), del también obispo astorgano Gonzalo, del 992 (QUINTANA PRIETO, 1968: 467), del obispo leonés Froilán, del 999 (MÍNGUEZ FERNÁNDEZ, 1976: 434), del abad Alfonso de San Martín de Salas en Asturias, de 1020 (GARCÍA LARRAGUETA, 1962: 147), de un frater Bictus donante al monasterio de San Juan de Corniero en 999 (MÍNGUEZ FERNÁNDEZ, 1976: 435), de un indeterminado Cromacius del monasterio de San Vicente de Oviedo, fechado en 1119 (FLORIANO LORENTE, 1968: 254), e, incluso, de un simple laico, como Bellacus, vendedor de una tierra al monasterio de Sahagún en 973 (MÍNGUEZ FERNÁNDEZ, 1976: 319). A ello se añade la perdida inscripción del ara de altar de San Miguel de Quiloño en Asturias, de fines del IX o primeros tiempos del X (GARCÍA DE CASTRO VALDÉS, 1995: 192). Los documentos compostelanos alusivos a donaciones de los reyes leoneses del siglo $X$ contienen diferentes intitulaciones con fórmulas de humildad muy similares a la de servus Christi: así, Ordoño Il y su esposa Elvira, Ordoño III con su cónyuge Urraca, y Sancho I se intitulan famuli Christi (LUCAS ÁLVAREZ, 1998: 84, 96, 116, 126), mientras el mismo Ordoño II, Fruela II, Ramiro II, Ordoño III y Alfonso V utilizan la fórmula servorum Domini servus (LUCAS ÁLVAREZ, 1998: 101, 102, 107, 110, 118, 120, 153, 156), atestiguándose igualmente la variante famuli Christi et servorum Dei en un documento de Ramiro II (IBIDEM: I I I). Fórmulas semejantes o idénticas fueron utilizadas por los notarios del obispo Gonzalo de León, quien, en sendas donaciones al monasterio de Sahagún, de los años 962 y 967 , se intitula, respectivamente, servus Domini servorum y servus servorum Dei (MÍNGUEZ FERNÁNDEZ, 1976: 243, 296), esta última compartida por Petrus Martiniz y su esposa, doanates a la sede astorgana en I077 (QUINTANA PRIETO, 1977: 593). Completa la serie el hecho de que la Vita Ildefonsi, debida a la pluma del también obispo toledano Cixila (745-754), califica por tres veces a lldefonso de servus Dei, sin atender a su doble condición de obispo y monje (GIL, 1973: I, 64-65). A mi entender, y a falta de estudio monográfico sobre esta cuestión, no se puede, por ello, conceder excesiva fuerza argumentativa a esta intitulación de Alfonso II.

Por su parte, en 799, víspera de la coronación imperial de Carlomagno, Alcuino se dirigía al monarca franco en términos que no dejan lugar a dudas sobre la ubicación jerárquica y el carácter absoluto de su poder:

Nam tres personae in mundo altissime hucusque fuerunt: id est, apostolica sublimitas, quae beati Petri principis apostolorum sedem vicario munere regere solet; quid vero in eo actum est, qui rector prefate sedis fuerat, mihi venerande bonitas vestra innotescere curavit. Alia est imperialis dignitas et secundae Romae secularis potentia; quam impie gubernator imperii illius depositus sit, non ab alienis, sed a propriis et concivibus, ubique fama narrante crebrescit. Tertia est regalis dignitas, in qua vos Domini nostri lesu Christi dispensatio rectorem populi christiani disposivit, ceteris praefatis dignitatibus potentia excellentiorem, sapientia clariorem, regni dignitate sublimiorem. Ecce in te solo tota salus eclesiarum Christi inclinata recumbit. Tu iudex scelerum, tu rector errantium, tu consolator marrentium, tu exaltatio donorum (DÜMMLER, 1994: 288).

No obstante, y a diferencia tanto de Alfonso II y Otón III, como de los emperadores bizantinos, Carlomagno rechazó siempre la condición isoapostólica, tal y como atestiguan los Libri Carolini (IV, 20), en su respuesta a las actas del II Concilio de Nicea (787), donde se postulaba explícitamente tal rasgo (SCHRAMM, 1984: 145).

\section{LA RUPTURA IDEOLOGICA}




\section{DE ALFONSO II A RAMIRO I EN SU TRASFONDO EUROPEO}

La diferencia más ostensible entre estos textos anteriores a Ramiro I (842-850) y los ya colacionados textos del altar de Naranco y sus paralelos litúrgicos estriba en el modo de donar. En los primeros, de acuerdo con los precedentes hispánicos, el donante ruega en primera persona, dialogando con el donatario directamente, sin intermediario. En los segundos, se ruega por el donante, quien aparece mencionado en una plegaria pronunciada por otros en un acto plenamente litúrgico. Encontramos nuevamente tras este análisis la misma cesura advertida tras comparar los textos de las laudes regiae. El proceso parece manifestarse homogéneo: en la primera fase, hasta los reinados de Carlomagno (+8I4) y Alfonso II (+842), y especialmente a caballo entre el siglo VIII y el IX, el soberano no precisa de intermediarios en su relación con los donatarios sobrenaturales de sus ofrendas y el clero actúa como caja de resonancia del poder político; en la segunda fase, desaparece la capacidad del soberano para dirigirse directamente a sus donatarios sobrenaturales: se ha impuesto la mediación clerical, que configura una liturgia específicamente política, en la que se embrida y sujeta la voluntad del poder civil. De un monarca identificado con David se deriva hacia un monarca cuya vida ha de modelarse conforme la de Salomón. A un monarca responsable ante Dios de la salvación del rebaño a él encomendado sucede un monarca penitente, por quien se implora el perdón divino. De Alfonso II, explícito nuevo Jacob, a Ramiro I, criptoSalomón, la transformación no puede ser más radical.

Parece, pues, que en el Reino de Asturias se cumple también el fenómeno histórico de la "clericalización" del pensamiento y el comportamiento político medieval que es patente en la monarquía franca a partir del reinado de Ludovico Pío (8 | 4-840), favorecido por el destacado papel jugado por los obispos Agobardo de Lyon y Ebbon de Reims y los abades Adalardo y Wala de Corbie a favor de los hijos de emperador, y del abad Benito de Aniano en las decisones políticas emprendidas por éste (ULLMANN, 1985: 72-88; HALPHEN, 1968: 199-260). El primer episodio que indica el cambio respecto a la precedente situación bajo Carlomagno fue la unión de las ceremonias de unción y coronación imperiales en Reims (816), cuando el papa Esteban IV coronó a Luis el Piadoso (BLOCH, 1988: 73). La práctica continuó en 823 -coronación de Lotario por Pascual I-, en 844 -unción de Luis II, hijo de Lotario, como rey de lombardos por Sergio IV, en 850 -coronación imperial de Luis II por León IV-, en un proceso de romanización de la idea imperial que desembocó en la elección papal del candidato bajo el pontificado de Juan VIII -Carlos el Calvo 875-877; Carlos el Gordo 88I- y Formoso -Arnulfo de Carintia, 896- (FOLZ, 1953: 40-44). En el caso del reinado de Ludovico Pío, como es bien sabido, la divergencia con los obispos partidarios de la unidad del Imperio y de su regulación en los términos establecidos por la Ordinatio Imperii del año 817 , tuvo como trasfondo, además del problema sucesorio sobrevenido con el segundo matrimonio del monarca y el nacimiento del futuro Carlos el Calvo, la voluntad episcopal de mantener el concepto de imperium ligado al de ministerium, subordinado a la misión providencial de garantizar la unidad de los cristianos bajo un solo poder político. A ello se unió en 832 la toma de partido del papa Gregorio IV, en sentido neogelasiano (BOSHOF, 1996: 173-175, 192-195).

La propia utilización de la idea de Renovatio Imperii Romani, divisa de Carlomagno, en manos de sus sucesores explicita el cambio: la fórmula fue sustituida por la de Renovatio Regni Francorum, de menor alcance, lo que favoreció que, desde el pontificado de León IV (847855), el papado se hiciese con ella, atribuyéndose el papel decisivo en el gobierno de la Cristiandad, a despecho de la efectiva autonomía ejercida y disfrutada por Carlomagno $(\mathrm{SCH}-$ RAMM, 1984: 42-50). Sólo bajo Otón III, en los últimos años del siglo $X$, resucitaría una concepción de supremacía del poder imperial, en la que no fue ajena la reverencia que el joven emperador sajón sintió por el primer Carlos.

La tendencia hacia el sometimiento simbólico del poder civil al eclesiástico alcanzó puntos álgidos en la deposición -tras el abandono en el "Campo de la mentira" de Colmar-y for- 
zada penitencia de Ludovico Pío en Saint Médard de Soissons (833), de la que hubo de desquitarse en las ceremonias de restitución llevadas a cabo en Thionville y Saint Étienne de Metz en 835. La muerte de Luis y el subsiguiente reparto del Imperio transfirieron al papado y a las asambleas conciliares (Coulaines, 843) la idea de unidad del pueblo cristiano, abriendo la puerta a la eclesialización del pensamiento político y la acción tutorial del episcopado sobre el monarca, que ya había expuesto Jonás de Orléans en la amonestación que el concilio de París había dirigido en 829 al emperador. En esta epístola, los prelados asistentes al concilio, tras exponer la doctrina gelasiana sobre la doble autoridad, real y sacerdotal, y tratar separadamente de los asuntos concernientes a ambos dominios, concluyeron su intervención con una relación de peticiones culminada por el capítulo $X X V I$, en que se dilucidaban las causas de la crítica situación del reino, en estos términos:

Nam et illud, quod in eisdem capitulis continentur, ut manifestum fieret, quae causae id effecerint, ut sacerdotes et principes a recto tramite deviassent, exceptis praemissiis capitulis, in quibus, sicut diximus, multa neglegebantur, specialiter tamen unum obstaculum ex multo tempore iam inolevisse cognovimus, id est quia et principalis potestas diversis occasionibus intervenientibus secus, quam auctoritas divina se habeat, in causas ecclesiasticas prosilient et sacerdotes partim neglegentia, partim ignorantia, partim cupiditate in saecularibus negotiis et sollicitudinibus mundi ultra, quam debuerant, se occupaverint; et hac occasione aliter, quam divina auctoritas doceat, in utraque parte actum extitisse dubium non est (WERMINGHOFF, 1979: 679-680; DEVISSE, 1975-1976: 697-698; HALPHEN, 1968: 277-281; BOSHOF, 1996: 175177).

El cambio de tono respecto a los laudatorios versos dirigidos a Carlomagno no puede ser más ostensible. Está admitido entre los historiadores que el redactor de los capítulos conciliares dedicados a examinar la autoridad civil - Liber II, De regibus et principibus- fue Jonás de Orléans, autor del tratado De Institutione regia, que reproduce el mismo texto (REVIRON, 1930).

Es significativo, en este sentido, el hecho de que ya bajo Ludovico Pío la legitimidad definitiva de la dignidad imperial residiera en el hecho de ser conferida por el Papa, lo que se deduce de la decisión del propio emperador de hacer coronar en Roma a su heredero Lotario el día de Pascua de 823, años después de haberlo proclamado él mismo emperador en Aquisgrán, lo que despertó las inevitables dudas sobre el valor de la cornación civil (SCHRAMM, 1984: 15). A la muerte de Lotario (855), las desavenencias continuas entre los tres herederos y sus dos tíos Carlos el Calvo y Luis el Germánico fortalecieron la influencia del episcopado, en especial de Hincmar de Reims, abanderado de los intereses de Carlos el Calvo, y del papado, fortalecido tras la actividad de Nicolás I (858867). De hecho, el dominio simbólico del episcopado ya se había hecho patente en la coronación, unción y entrega de cetro de Carlos el Calvo por el arzobispo de Sens en 848 (BLOCH, 1988: 424). A partir de la muerte de Luis II, hijo de Lotario, (875) se hizo patente el decisivo papel que el acto litúrgico de coronación jugaba a efectos de conferir la legitimidad política: el propio Luis había sido el primer emperador coronado como tal en Roma sin proclamación previa desde Carlomagno, y a su muerte sin descendencia el papa procedió a la coronación de Carlos el Calvo, en manifestación palpable de posesión de la legitimidad imperial $(\mathrm{SCH}-$ RAMM, 1934: 122-124; SCHRAMM, 1984: 15; HALPHEN, 1968: 358-360). No puede ser casualidad que sólo a partir de la coronación de Judith, hija de Carlos el Calvo (Verberie, 856) se conserven noticias de ordines de coronación ( $\mathrm{SCH}$ RAMM, 1934: 120), cuya característica principal estriba en la obtención de garantías de sumisión del monarca mediante la promissio ante el altar, previa a la ceremonia. Corrobora este desarrollo el estudio comparativo de las fórmulas de juramento de fidelidad al soberano (ODEGAARD, 1945: 279-289). Así, en los dos textos conservados de Carlomagno (789 y 802), el súbdito juraba fidelidad domino piissimo imperatori ... sicut per drictum debet esse homo domino suo, fórmula en la que se ha querido ver expresada una relación de sumisión privada incondicional al señor. Por el contrario, las fórmulas recogidas en los textos provenientes del reinado de Carlos el Calvo, establecen el juramento sicut Francus homo per rectum esse debet 
suo regi (854), refiriéndose a la potestad quam in regio nomine et regno vobis Deus concessit (858) o al regnum, quod vobis Deus donavit vel donaverit (872). En opinión de Odegaard, el uso de términos del campo semántico de rex implica sin duda una limitación en el poder absoluto del gobernante, que el mismo autor pone en relación con el retorno de concepciones políticas de derecho público. En cualquier caso, se hizo patente en la discusión sobre la fórmula del juramento regio de Ponthion (876) la confrontación entre la voluntad del monarca, reacio a admitir recortes en su potestad, y la del estamento eclesiástico, cuya opinión se expresa en la pluma de Hincmar de Reims, quien argumentó en favor de la supresión del juramento isti seniori meo, proponiendo en su lugar la fórmula isti imperatori. El resultado fue la obtención de una fórmula de compromiso, aplicada en el pacto de Meersen (85I), de este tenor: sicut per rectum unusquisque in suo ordine et statu suo principi et suo seniori esse debet (IBID, 283-289).

\section{A MODO DE CONCLUSIÓN: HIPÓTESIS SOBRE LA RAZÓN DE LOS EDIFICIOS DEL NARANCO}

Ahora bien, es preciso intentar cernir históricamente las circunstancias que provocaron el cambio que se aprecia entre los textos analizados del testamentum de Alfonso II y la inscripción de Naranco, en lo que se refiere a la teología política. De acuerdo con cuanto venimos exponiendo, Ramiro I actúa sometido al dictado de instancias eclesiásticas, imprimiendo a su ofrenda un marcado acento penitencial, que ni siquiera osa remitirse directa y explícitamente al paradigma de los constructores de templos, Salomón. La inscripción, que debe interpretarse como signo del fin de la obra, lleva la fecha de 23 de junio de 848, unos seis años después de la muerte de su antecesor Alfonso II, fallecido en marzo de 842. Es bien sabido que las circunstancias del acceso al trono de Ramiro I fueron violentas. El hijo de Vermudo I se impuso, tras un golpe de estado, a Nepociano, cuñado de Alfonso Il, según recoge la Nomina regum catolicorum legionensium, contenida en los tres códices Emilianense, Albeldense y Rotense en los que se han transmitido las más antiguas copias de la Crónica Albeldense (GIL ET AL, 1985: 172; Alb, XVa: Deinde Nepotianus cognatus regis Adefonsi). Este personaje, a quien la tendenciosa historiografía alfonsí calificó de tirano (GIL ET AL, 1985: 142-143; Crón. Ad. III, versio Rot, 23: Nepotianus palatii comes regnum tirannide est adeptus; versio ad Seb, 23: accidit ut Nepotianus palatii comes regnum sibi tyrannice usurpaset), permaneció al menos año y medio en el poder, antes de que fuese expulsado del mismo, cegado y recluido en un monasterio por su rival Ramiro I (SÁNCHEZ ALBORNOZ, 1972-1975: III, 4042). A título hipotético podría pensarse que el ataque normando a las costas cantábricas pudo ser incentivado por el propio Nepociano en lucha frente a su rival. De este modo, habría respondido el ataque a una práctica de las primeras apariciones vikingas en Europa occidental, en ocasiones reclamadas como auxiliares por alguno de los participantes en las múltiples luchas políticas de la Europa atlántica postcarolingia, o aprovechadas por los mismos, lo que despertaba la más unánime condena moral del responsable de esta conducta (Ó CROIINIíN, 1995: 250-25I; SMYTH, 1995: 80-85). En todo caso, es verosímil que en Asturias las cosas hubiesen discurrido de modo semejante a como sucedieron en el resto de la Europa atlántica sacudida por las invasiones escandinavas en el siglo IX. Es decir, un encuentro militar no definitivamente resuelto era completado y solventado con un pacto o tratado, por el que, contra pago, se contenía temporalmente la presión del invasor. Todo ello es hipotético, aunque verosímil, sobre todo si se renuncia a considerar las narraciones de los hechos por parte de la historiografía asturiana como rigurosamente fieles a la realidad de los mismos, prescindiendo de su patente sesgo dinástico e ideológico.

Una vez superada la amenaza nórdica, la situación de guerra civil continuó con igual virulencia: Ramiro hizo frente a dos sucesivas rebeliones, las de los comites palatini Aldroitus y Piniolus (GIL ET AL, 1985: I44-145, 175; Crón Adef III, versio Rot, 24; versio ad Seb, 24; Crón Alb, XV, 10), que acabaron con la victoria de Ramiro. Se desprende de esta situación que la llegada al poder de éste fue percibida como ilegítima por el entorno cortesano ovetense, lo que provocó 
la resistencia de al menos dos miembros cualificados de ese entorno, si es que no fueron más las rebeliones, como apuntó Sánchez Albornoz (1972-1975: III, 65-67). Quizás estribe en esta circunstancia la fundación de Naranco y Lillo, alejados del núcleo de Oviedo y en posición favorable ante un hipotético ataque desde la capital: Ramiro no gozó de las simpatías de los dirigentes de la ciudad $y$, consciente de ello y de los peligros que de lo mismo pudieran derivarse, se instaló in latere montis Naurantii, al abrigo de cualquier ataque imprevisto. El lugar se denominaba a la sazón Ligno, según atestigua la Albeldense $(X V, I 0)$, y en él, de enfermedad, murió el monarca -lbique a saeculo recessit-. No sería de extrañar que a esta circunstancia se debieran los caracteres excepcionales que revisten tanto la propia inscripción como el conjunto de edificios que aún esconden múltiples secretos. La erección del altar puede interpretarse en términos de expiación y reconciliación por parte de un soberano alzado violentamente al poder, sometido verosímilmente al trance de pactar con paganos, y cuyo reinado se caracterizó por la perpetuación de la violencia. La fórmula empleada, aludiendo a la acción de Salomón, responde tanto a las circunstancias particulares ovetenses como a la tendencia en la Europa occidental coetánea. Es posible que, tras la aparente objetividad litúrgica de su texto, se esconda el pacto por el que Ramiro I situó en la línea sucesoria a su hijo Ordoño, afirmando definitivamente la hereditariedad del trono en el Reino de Asturias.

\section{BIBLIOGRAFÍA}

ABADAL I DE VINYALS, Ramón d' (1952): Catalunya carolíngia. II. Els diplomes carolingis a Catalunya. Institut d'Estudis Catalans, Barcelona.

ALFÖLDI, Andreas (1980): Die monarchische Repräsentation im römischen Kaiserreiche, Wissenschaftliche Buchgesellschaft, Darmstadt.

ARBEITER, Achim y NOACK-HALEY, Sabine (1999): Hispania Antiqua. Christliche Denkmäler des frühen Mittelalters. Von 8. bis ins XI. Jahrhundert. Deutsches Archäologisches Institut-Philipp Von Zabern, Maguncia.
ALTHOFF, Gerd (1996): Otto III. Wissenschaftliche Buchgesellschaft, Darmstadt.

AYUSO MARAZUELA, Teófilo (1953): La Vetus latina hispana. Madrid.

AYUSO MARAZUELA, Teófilo (1956): La biblia visigótica de la Cava dei Tirreni. Contribución al estudio de la Vulgata en España. Consejo Superior de Investigaciones Científicas, Madrid.

BANGO TORVISO, Isidro Gonzalo (1988): "Alfonso II y Santullano", II Jornadas sobre arte prerrománico y románico en el Norte de España, Villaviciosa, pp. 207-239.

BANGO TORVISO, Isidro Gonzalo (1992): "Los reyes y el arte durante la Alta Edad Media: Leovigildo y Alfonso Il y el arte oficial", Ephialte. Lecturas de Historia del Arte, pp. 19-32.

BARBERO DE AGUILERA, Abilio (1985): "Los síntomas españoles y la política religiosa de Carlomagno", En la España medieval, pp. 87-I 38.

BINDING, Günther (1996): Der früh- und hochmittelalterliche Bauherr als sapiens architectus, Wissenschaftliche Buchgesellschaft, Darmstadt.

BLOCH, Marc (1988): Los reyes taumaturgos, Fondo de Cultura Económica, México.

BLUME, Clemens (1897): Hymnodia Gothica, Analecta Hymnica Medii Aevii, 27, Leipzig.

BOSHOF, Egon (1996): Ludwig der Fromme. Wissenschaftliche Buchgesellschaft, Darmstadt.

BROU, Louis, y VIVES, José ( 1959): Antifonario de la catedral de León, Monumenta Hispaniae Sacra, V-I, Consejo Superior de Investigaciones Científicas, Barcelona-Madrid.

CAILLET, Jean-Pierre (1993): L'évergétisme monumental chrétien en Italie et à ses marges, École française de Rome, Roma.

CAMPOS, Julio (1960): Juan de Bíclaro, obispo de Gerona. Su vida y su obra, Consejo Superior de Investigaciones Científicas, Madrid.

CAMPS CAZORLA, Emilio (1948): "Revisión de algunos problemas de los monumentos ramirenses", Boletín del Instituto de Estudios Asturianos, 5, pp. 95-I26.

CANELLA SECADES, Fermín ( 1884$)$ : Estudios asturianos (cartafueyos d'Asturies). Oviedo.

CANELLAS LÓPEZ, Ángel (1979): Diplomática hispanovisigoda. Institución Fernando el Católico, Zaragoza.

CASPAR, Erich, LAEHR, Gerhard et al (1993): Epistolae Karolini Aevi, V. Monumenta Germaniae Historica, Epistolae, 7. Munich ( ${ }^{\mathrm{a}}$ ed., Berlín, Weidmannsche Verlagbuchgesellschaft, 1928).

CLAUDE, Dietrich (197I): Adel, Kirche und Königtum im Westgotenreich, Jan Thorbecke, Sigmaringen. 
COLUNGA, Alberto y TURRADO, Lorenzo (1985): Biblia sacra iuxta Vulgatam Clementinam. Editorial Católica, Biblioteca de Autores Cristianos, Madrid.

DEVISSE, Jean (1975-1976): Hincmar, archevêque de Reims 845-882, Droz, Genève.

DIEGO SANTOS, Francisco (1994): Inscripciones medievales de Asturias. Principado de Asturias, Oviedo.

DUMAS, A. (198|): Liber Sacramentorum gellonensis. Corpus Christianorum, Series latina CLIX-CLIXA, Brepols, Turnholti.

DÜMMLER, Ernst (1978a): Poetae Latini Aevi Carolini. Monumenta Germaniae Historica, Poetarum Latinorum Medii Aevi, II, Munich ( ${ }^{\text {a }}$ ed. Berlin, Apud Weidmannos, I884).

DÜMMLER, Ernst (1978b): Poetae Latini Aevi Carolini. Monumenta Germaniae Historica, Poetarum Latinorum Medii Aevi, I, Munich ( ${ }^{a}$ ed. Berlin, Apud Weidmannos, I88I).

DÜMMLER, Ernst (1994): Epistolae Karolini Aevi II. Monumenta Germaniae Historica, Epistolae IV, Munich (I ${ }^{\text {a }}$ ed: Berlin, Apud Weidmannos, 1895).

DÜMMLER, Ernst y GUNDLACH, Wilhelm (1994): Epistolae Merowingici et Karolini Aevi I. Monumenta Germaniae Historica, Epistolae III, Munich (I ${ }^{a}$ ed: Berlin, Apud Weidmannos, 1892).

DÜMMLER, Ernst, HAMPE, Karl, et al (1995): Epistolae Karolini Aevi, III. Monumenta Germaniae Historica, Epistolae V, Munich ( ${ }^{a}$ ed: Berlín, Apud Weidmannos, 1899).

DÜMMLER, Ernst y PERELS, Ernst (1995): Epistolae Karolini Aevi IV, Monumenta Germaniae Historica, Epistolae VI, Munich (I ed: Berlín, Apud Weidmannos, 1925).

ESCORTELL PONSODA, Matilde (1975): Catálogo de las salas de arte prerrománico del Museo Arqueológico Provincial. Diputación Provincial, Oviedo.

EWIG, Eugen (1987): "La Iglesia bajo el dominio de los laicos", Manual de Historia de la Iglesia (Hubert Jedin, ed.), III, Herder, Barcelona.

FICHTENAU, Heinrich (1949): Das karolingische Imperium. Fretz \& Wasmuth, Zürich.

FICHTENAU, Heinrich (1992): Lebensordnungen des I0.Jahrhunderts. DTV Wissenschaft, Munich.

FLORIANO CUMBREÑO, Antonio Cristino (1949-1950): Diplomática española del período astur, 2 vols, Instituto de Estudios Asturianos, Oviedo.

FOLZ, Robert (1953): L'idée d'empire en Occident du Ve. Au XIVe. Siècle. Aubier, Éditions Montaigne, París.

FOLZ, Robert (1989): Le couronnement impérial de Charlemagne. 25 décembre 800. Gallimard, París.

GARCÍA LARRAGUETA, Santos (1962): Colección de documentos de la Catedral de Oviedo. Instituto de Estudios Asturianos, Oviedo.
GARCÍA DE CASTRO VALDÉS, César (1995): Arqueología cristiana de la Alta Edad Media en Asturias. Real Instituto de Estudios Asturianos, Oviedo.

GARCÍA DE CASTRO VALDÉS, César (1999a): "El altar procedente de Santa María de Naranco", Nuestro Museo. Boletín del Museo Arqueológico de Asturias, I, pp. 49-58.

GARCÍA DE CASTRO VALDÉS, César (1999b): "Las primeras fundaciones", en: CASO, Francisco de, CUESTA, Cosme, GARCÍA DE CASTRO, César, HEVIA, Jorge, MADRID, Vidal de la, RAMALLO, Germán: La Catedral de Oviedo. I Historia y Restauración; II Catálogo y Bienes Muebles, Nobel, Oviedo, I, pp. 21-73.

GIERLICH, Ernst (1990): Die Grabstätten der rheinischen Bischöfe vor 1200. QAMRhKG, 65, Gesellschaft für mittelrheinische Kirchengeschichte, Mainz.

GIL, Juan (1973): Corpus scriptorum muzarabicorum. Consejo Superior de Investigaciones Cientíicas-Instituto Antonio de Nebrija, Madrid.

GIL, Juan (1977): "Judíos y cristianos en la Hispania del siglo VII", Hispania Sacra, XXX, PP. 9-I I0.

GIL, Juan (|99|): Miscellanea wisigothica. Universidad de Sevilla, Sevilla.

GIL, Juan, MORALEJO, José Luis, RUIZ DE LA PEÑA, Juan Ignacio (1985): Crónicas asturianas, Universidad de Oviedo, Oviedo.

HACK, Achim Thomas (1999): "Das Zeremoniell des Papstempfangs 799 in Paderborn", 799 Kunst und Kultur der Karolingerzeit, Beiträge zum Katalog der Ausstellung (Christoph Stiegemann y Matthias Wiemhoff, eds.), Philipp Von Zabern, Maguncia, pp. 19-33.

HALPHEN, Louis (1968): Charlemagne et l'empire carolingien, Albin Michel, París.

HANSSENS, lohannes Michaelis (1948-50): Amalarii episcopi Opera Liturgica omnia, Biblioteca Apostolica Vaticana, Studi e Testi 138-140, Città del Vaticano

HOLTZMANN, Robert (1980): Die Chronik des Bischofs Thietmar von Merseburg, Monumenta Germaniae Historica, Scriptores Rerum Germanicarum, Nova Series, IX, Munich (I ${ }^{\text {a }}$ ed., Berlín, Weidmannsche Verlagbuchhandlung, 1935).

HAUPT, Albrecht (1935): Die älteste Kunst, insbesondere die Baukunst der Germanen. Berlín.

HEIMING, O. (1984): Liber Sacramentorum augustodunensis, Corpus Christianorum, Series latina, CLIXB, Brepols, Turnholti.

IÑIGUEZ ALMECH, Francisco (1955): "Algunos problemas de las viejas iglesias españolas", Cuadernos de trabajo de la Escuela Española de Historia y Arqueología en Roma, VII, pp. 7-I 80.

ISLA FREZ, Armando (1998): Realezas hispánicas del año mil, Publicacións do Seminario de Estudos Galegos, Edicións do Castro, A Coruña. 
JANINI CUESTA, José (1979): Liber Misticus de Cuaresma, Instituto de Estudios Visigótico-Mozárabes, Toledo.

JANINI CUESTA, José (1980): Liber Misticus de Cuaresma y Pascua, Instituto de Estudios Visigótico-Mozárabes, Toledo.

JANINI CUESTA, José (198I): Liber ordinum sacerdotal (Ms. 3 del monasterio de Silos). Studia Silensia, VII, Monasterio de Silos, Burgos.

JANINI CUESTA, José ( 1982): Liber Missarum de Toledo, 2 vols., Instituto de Estudios Visigótico-Mozárabes, Toledo.

JANINI CUESTA, José (|99|): Liber ordinum episcopal (Cód. Silos, A.M. 4). Studia Silensia, XV, Monasterio de Silos, Burgos.

JASKI, Bart (2000): Early Irish Kingship and Succesion. Four Courts Press, Dublín.

JORGE ARAGONESES, Manuel (1953): "El altar de Santa María de Naranco, notas para la restauración de su podio", Boletín del Instituto de Estudios Asturianos, XVIII, pp. 3-3I.

KANTOROWICZ, Ernst (1942): "Ivories and litanies", Journal of the Warburg and Courtauld Institute, V. pp. 568I (trad it: "Avori e canti liturgici", La sovranità dell'artista, Venecia, Marsilio, 1995, pp. |8|-214).

KANTOROWICZ, Ernst (1946): Laudes regiae. A study in mediaeval political Worship. Berkeley-Los Ángeles.

KANTOROWICZ, Ernst (1985): Los dos cuerpos del rey. Un estudio de teología política medieval, Alianza Editorial, Madrid.

KING, P. D. (|98I): Derecho y sociedad en el reino visigodo, Alianza Editorial, Madrid.

KRINKE, Johannes (1954): "Die spanische Taufritus im frühen Mittelalter", Spanische Forschungen der Görresgesellschaft, pp. 3-।I6.

KRUSCH, Bruno (1969): Gregorii Episcopi Turonensis miracula et opera minora, Monumenta Germaniae Historica, Scriptores Rerum Merowingicarum, I pars II, Hannover, Hahnsche Buchhandlung ( $I^{\text {a }}$ ed., Hannoverae, Impensis Bibliopolii Hahnani, 1885)

KRUSCH, Bruno (1995): Passiones Vitaeque Sanctorum Aevi Merowingici, Monumenta Germaniae Historica, Scriptores Rerum Merowingicarum, III, Hannover, Hahnsche Buchhandlung ( $I^{\text {a }}$ ed., Hannoverae, Impensis Bibliopolii Hahnani, 1896).

KRUSCH, Bruno y LEVISON, Wilhelm (1979a): Passiones Vitaeque Sanctorum Aevi Merowingici, Monumenta Germaniae Historica, Scriptores Rerum Merowingicarum, VII, Hannover, Hahnsche Buchhandlung ( ${ }^{\text {a }}$ ed., Hannoverae et Lipsiae, Impensis Bibliopolii Hahnani, 1920).

KRUSCH, Bruno y LEVISON, Wilhelm (1979b): Passiones Vitaeque Sanctorum Aevi Merowingici, Monumenta Germaniae Historica, Scriptores Rerum Merowingicarum, VI, Hannover ( ${ }^{\text {a }}$ ed., Hannoverae et Lipsiae, Impensis Bibliopolii Hahnani, 19|3).
KRUSCH, Bruno y LEVISON, Wilhelm (1993): Gregorii Episcopi Turonensis Libri Historiarum X, Monumenta Germaniae Historica, Scriptores Rerum Merowingicarum, I, pars I, Hannover, Hahnsche Buchhandlung ( $I^{a}$ ed., Hannoverae, Impensis Bibliopolii Hahnani, 195I).

LUCAS ÁLVAREZ, Manuel (1998): Tumbo A de la catedral de Santiago. Estudio y edición. Seminario de Estudos Galegos-Cabildo de la S.A.M.I. Catedral, Santiago.

MARTíNEZ DÍEZ, Gonzalo y RODRÍGUEZ, Félix (1992): La colección canónica hispana, V. Concilios hispanos: segunda parte. Consejo Superior de Investigaciones CientíficasInstituto Enrique Flórez, Madrid.

MIGUEL VIGIL, Ciriaco ( 1887 ): Asturias monumental, epigráfica y diplomática. Diputación Provincial, Oviedo.

MÍNGUEZ FERNÁNDEZ, José María (1976): Colección diplomática del monasterio de Sahagún (siglos IX-X). Centro de Estudios e Investigaciones San Isidoro, León.

MÜHLBACHER, Engelbert (|99|): Die Urkunden Pippins, Karlmanns und Karls des Grossen. Monumenta Germaniae Historica. Die Urkunden der Karoliner (Diplomata Karolinorum), I. Munich.

MUNDÓ, Anscari Manuel (1961): "La inscripción de Samos", Studia Monastica, pp. 157-164.

MUSSET, Lucien (1982): Las invasiones. El segundo asalto contra la Europa cristiana (siglos VII-XI). Labor, Barcelona

MUSSET, Lucien (1998): "Basse Normandie", DUVAL, Noël (ed.): Les premiers monuments chrétiens de la France, III, Ministère de la Culture et de la Francophonie-Picard, París, pp. 278-284.

NAVASCUÉS, Joaquín María de (196|): La dedicación de San Juan de Baños. Palencia.

Ó CROÍNíN, Dáibhí (1995): Early medieval Ireland, Longman, Londres-Nueva York.

ODEGAARD, Charles Edwin (1945): "The Concept of Royal Power in carolingians Oaths of Fidelity", Speculum, XX-3, pp. 279-289.

OSTROGORSKY, Georg (1984): Historia del estado bizantino, Akal, Madrid.

OTT, Irene (1958): Ruotgers Lebensbeschreibung des Erzbischofs Bruno von Köln. Monumenta Germaniae Historica, Scriptores Rerum Germanicarum, Nova Series, X, Köln-Graz, Böhlau Verlag.

PERELS, Ernst (1985): Die Briefe des Erzbischofs Hinkmar von Reims (Hincmari Archiepiscopus Remensis Epistolae),Epistola Karolini Aevi, VIII, Monumenta Germaniae Historica, Epistolae, VIII.I, Munich (I ${ }^{\text {a }}$ ed: Berlin, Weidmannsche Verlagbuchhandlung)

PÉREZ DE URBEL, Justo (1952): Sampiro, su crónica y la monarquía leonesa en el siglo X. Consejo Superior de Investigaciones Científicas, Madrid. 
PÉREZ DE URBEL, Justo y GONZÁLEZ RUIZ-ZORRILLA, Atilano (1950- 1955): Liber Commicus. Monumenta Hispaniae Sacra, Serie litúrgica, II-II, Consejo Superior de Investigaciones Científicas, Madrid.

PERTZ, Georg Heinrich (1925a): Monumenta Germaniae Historica, Scriptorum II, Karl W. Hiersemann, Leipzig (I ${ }^{\text {a }}$ ed, Hannoverae, Impensis Bibliopolii Aulici Hahnani, I829).

PERTZ, Georg Heinrich (1925b): Monumenta Germaniae Historica, Scriptorum IV, Karl W. Hiersemann, Leipzig (I ${ }^{\text {a }}$ ed, Hannoverae, Impensis Bibliopolii Aulici Hahnani, |84I).

PINELL, Jorge (1972): Liber orationum psalmographus. Colectas de salmos del antiguo rito hispánico. Monumenta Hispaniae Sacra, Serie Litúrgica, IX, Consejo Superior de Investigaciones Científicas-Instituto Enrique Flórez, Barcelona-Madrid.

PRADO, Germán (1926): Textos inéditos de la liturgia mozárabe. Junta para la Ampliación de Estudios e Investigaciones Científicas-Centro de Estudios Históricos, Madrid.

QUINTANA PRIETO, Augusto (1968): El obispado de Astorga en los siglos IX y X. Archivo Diocesano de Astorga, Astorga.

QUINTANA PRIETO, Augusto (1977): El obispado de Astorga en el siglo XI. Astorga.

REVIRON, Jean (1930): Les idées politico-religieuses d'un évêque du IXe siècle. Jonas d'Orléans et son De institutione regia, J. Vrin, Paris.

REYNAUD, Jean-François (1995): "Rhône-Alpes", DUVAL, Noël (ed.): Les premier monuments chrétiens de la France, I, Ministère de la Culture et la Francophonie-Picard, París, pp. 190-195.

RICHÉ, Pierre (1995): Éducation et culture dans l'Occident barbare. Seuil, París.

RICHÉ, Pierre (2000): Les carolingiens. Une famille qui fit l'Europe. Hachette, París.

RIGHETTI, Mario (1955): Historia de la liturgia, I: Introdución general. El año litúrgico. El breviario, Editorial Católica, Biblioteca de Autores Cristianos, Madrid.

RODRÍGUEZ ALONSO, Cristóbal (1975): Las historias de los godos, vándalos y suevos de Isidoro de Sevilla, Centro de Estudios e Investigación San Isidoro, León.

RODRÍGUEZ DÍAZ, Elena (1995-97): "Notas codicológicas sobre el llamado Testamento del Rey Casto", Asturiensia Medievalia, 8, pp. 7I-78.

SÁEZ, Emilio (1987): Colección documental del Archivo de la Catedral de León I (775-952). Centro de Estudios e Investigación San Isidoro, León.

SÁEZ, Emilio y SÁEZ, Carlos (1996): Colección diplomática del monasterio de Celanova (842-1230). I: 842-942, Universidad de Alcalá de Henares, Alcalá de Henares.

SAINT ROCH, Patrick (1987): Liber Sacramentorum Engolismensis, Corpus Christianorum, Series latina, CLIXC, Brepols, Turnholti.
SÁNCHEZ ALBORNOZ, Claudio (1972-1975): Orígenes de la nación española. El Reino de Asturias, 3 vols., Instituto de Estudios Asturianos, Oviedo.

SCHEIBELREITER, Georg (1999): Die barbarische Gessellschaft. Mentalitätsgeschichte der europäischen Achsenzeit, 5.-8. Jahrhundert. Wissenschaftliche Gessellschaft, Darmstadt.

SCHIEFFER, Theodor (1995): Die Urkunden Lothars I und Lothars II. Monumenta Germaniae Historica, Die Urkunden der Karolinger III (Diplomata Karolinorum), Munich (I a ed: Berlín-Zürich, Weidmannsche Verlagbuchhandlung, 1966).

SCHLUNK, Helmut (1947): "Arte visigodo. Arte asturiano", Ars Hispaniae, II, Plus Ultra, Madrid, pp. 325-4I6.

SCHLUNK, Helmut (1948): "La decoración de los monumentos ramirenses", Boletín del Instituto de Estudios Asturianos, 5, pp. 55-94.

SCHLUNK, Helmut (1976-1980): "El arte asturiano en torno al 800", Actas del Simposio para el estudio de los códices del Comentario al Apocalipsis de Beato de Liébana, Madrid, pp. 137-I64.

SCHLUNK, Helmut y HAUSCHILD, Theodor (1978): Hispania Antiqua. Die Denkmäler der frühchristlichen und westgotischen Zeit, Deutsches Archäologisches Institut-Philipp Von Zabern, Maguncia.

SCHRAMM, Percy Ernst (1934): "Die Krönung bei den Westfranken und Angelsachsen von 878 bis um 1000", Zeitschrift für Rechtsgeschichte, Kanonistische Abteilung, pp. 117-242

SCHRAMM, Percy Ernst (1935): "Die Krönung in Deutschland bis zum Beginn des salischen Hauses", Zeitschrift für Rechtsgeschichte, Kanonistische Abteilung, pp. 184-332.

SCHRAMM, Percy Ernst (1963): "Das Alte und das Neue Testament in der Staatslehre und Staatssymbolik des Mittelalters", La Bibbia nell'alto medioevo, Settimane di Studio del Centro Italiano de Studi sull'alto medioevo, Spoleto, pp. 229-255.

SCHRAMM, Percy Ernst (1984): Kaiser, Rom und Renovatio. Wissenschaftliche Buchgesellschaft, Darmstadt.

SMYTH, Alfred P. (1995): King Alfred the Great, Oxford University Press, Oxford.

SPITZBART, Günter, ed. (1997): Beda der Ehrwürdige. Kirchengeschichte des englischen Volkes, Wissenschaftliche Buchgesellschaft, Darmstadt.

STENTON, Frank M. (1947): Anglosaxon England, Oxford University Press.

STROHEKER, Karl Friedrich (1965): Germanentum und Spätantike, Zürich-Stuttgart.

TRAUBE, Ludwig (1978): Poetae Latini Aevi Carolini. Monumenta Germaniae Historica, Poetarum Latinorum, Medii

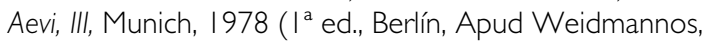
1886-96). 
UDINA MARTORELL, Federico (195I): El archivo condal de Barcelona en los siglos IX y X. Estudio crítico de sus fondos, Consejo Superior de Investigaciones Científicas, Barcelona.

ULLMANN, Walter (1985): Historia del pensamiento político en la Edad Media, Ariel, Barcelona ( $2^{\mathrm{a}}$ ed inglesa, 1970).

VALDÉS GALLEGO, José Antonio (2000): El Liber Testamentorum ovetensis. Estudio filológico y Edición, Real Instituto de Estudios Asurianos, Oviedo.

VIVES, José (1944): "Características hispánicas de las inscripciones visigodas", Arbor 2 (marzo-abril), pp. 185-199.

VIVES, José y CLAVERAS, J. (1946): Oracional visigótico, Monumenta Hispaniae Sacra, I, Consejo Superior de Investigaciones Científicas, Barcelona.
VOGEL, Cyrille y ELZE, Reinhard (1963): Le pontifical romano-germanique du dixième siècle. Le texte. Studi e testi, 226227. Città del Vaticano, Biblioteca Apostolica Vaticana.

VOLLMER, Friedrich (1984): Flavii Merobaudis Reliquiae; Blosii Aemilii Dracontii Carmina; Eugenii Toletani Episcopi Carmina et Epistolae, Monumenta Germaniae Historica, Auctores Antiquissimi, I4, Munich (I ${ }^{\text {a }}$ ed., Berlin, Apud Weidmannos, 1905).

WEBER, Robert (1945): Les anciennes versions latines du deuxième livre des Paralipomènes (Collectanea Biblica Latina, VIII), Libreria Vaticana-Abbaye Saint Jérôme, Città del Vaticano- Roma.

WERMINGHOFF, Albert (1979): Concilia Aevi Karolini, I, II. Monumenta Germaniae Historica, Legum, Sectio III, Concilia II, Hahnsche Buchhandlung, Hannover ( I ${ }^{\mathrm{a}}$ ed, Hannoverae et Lipsiae, Impensis Bibliopolii Hahniani, 1908). 